\title{
Angiogenesis in multiple sclerosis and experimental autoimmune encephalomyelitis
}

\author{
Francesco Girolamo ${ }^{1}$, Cristiana Coppola ${ }^{1}$, Domenico Ribatti ${ }^{1,2+}$ and Maria Trojano ${ }^{1 *+}$
}

\begin{abstract}
Angiogenesis, the formation of new vessels, is found in Multiple Sclerosis (MS) demyelinating lesions following Vascular Endothelial Growth Factor (VEGF) release and the production of several other angiogenic molecules. The increased energy demand of inflammatory cuffs and damaged neural cells explains the strong angiogenic response in plaques and surrounding white matter. An angiogenic response has also been documented in an experimental model of MS, experimental allergic encephalomyelitis (EAE), where blood-brain barrier disruption and vascular remodelling appeared in a pre-symptomatic disease phase. In both MS and EAE, VEGF acts as a pro-inflammatory factor in the early phase but its reduced responsivity in the late phase can disrupt neuroregenerative attempts, since VEGF naturally enhances neuron resistance to injury and regulates neural progenitor proliferation, migration, differentiation and oligodendrocyte precursor cell (OPC) survival and migration to demyelinated lesions. Angiogenesis, neurogenesis and oligodendroglia maturation are closely intertwined in the neurovascular niches of the subventricular zone, one of the preferential locations of inflammatory lesions in MS, and in all the other temporary vascular niches where the mutual fostering of angiogenesis and OPC maturation occurs. Angiogenesis, induced either by CNS inflammation or by hypoxic stimuli related to neurovascular uncoupling, appears to be ineffective in chronic MS due to a counterbalancing effect of vasoconstrictive mechanisms determined by the reduced axonal activity, astrocyte dysfunction, microglia secretion of free radical species and mitochondrial abnormalities. Thus, angiogenesis, that supplies several trophic factors, should be promoted in therapeutic neuroregeneration efforts to combat the progressive, degenerative phase of MS.
\end{abstract}

Keywords: Angiogenesis, Blood-Brain Barrier, Experimental Autoimmune Encephalomyelitis, Multiple Sclerosis, Neuroprotection, Neurovascular uncoupling, Neurovascular unit, Vascular Endothelial Growth Factor

\section{Angiogenesis in MS}

Multiple Sclerosis (MS) is an autoimmune demyelinating disease of the Central Nervous System (CNS) whose cause remains elusive. An inappropriate recognition of an autoantigen on myelinated nerve fibers recruits macrophages and lymphocytes in the CNS, leading to white and grey matter demyelination. Other pathological hallmarks of the disease are gliosis, axon degeneration and remyelination attempts.

An altered Blood-Brain Barrier (BBB) permeability, with a subsequent transmigration of lymphocytes and mediators into the CNS, is an early event in the MS pathogenesis. Local breakdown of BBB has been demonstrated, as gadolinium-DTPA enhancement (gd.e.) on T1 weighted magnetic resonance imaging (MRI), to

\footnotetext{
* Correspondence: maria.trojano@uniba.it

${ }^{\dagger}$ Equal contributors

'Department of Basic Medical Sciences, Neurosciences and Sense Organs, University of Bari 'Aldo Moro', Piazza Giulio Cesare, 11, 70124 Bari, Italy Full list of author information is available at the end of the article
}

precede other clinical signs and to be a prominent event in disease progression [1,2]. BBB incompetence has also been documented as an altered expression of endothelial tight junction proteins, changes of vascular basement membrane (BM) molecules and pericytes in acute and progressive MS forms [3-10]. Localized BBB disruption could precede the development of typical demyelinating lesions associated with inflammatory cuffs around veins or venules $[1,2,11,12]$. However, macrophage infiltration also seems possible across a preserved BBB for humoral factors (marked by the absence of gd.e.), as already demonstrated in MS [13,14] and EAE [15]. The increased BBB permeability is primarily, but not only, driven by the release of Vascular Endothelial Growth Factor (VEGF)/vascular permeability factor [16], that also regulates vessel growth and is chemotactic for monocytes and lymphocytes, promoting neuroinflammation [17-19]. Other BBB permeability promoting factors such as interferon- $\gamma$ (IFN- $\gamma$ ), tumour 
necrosis factor- $\alpha$ (TNF- $\alpha$ ) and interleukin-1 (IL-1) have been described in MS [reviewed in 7] (Table 1).

So-called sprouting angiogenesis, the formation of new vessels from pre-existing ones, is a strictly controlled process during tissue repair and regeneration to provide the necessary oxygen and nutrients for an area with increased cellular needs. Angiogenesis is a vital process in growth and organ development; it is active in developing human CNS [20] but quiescent in adult human brain [21]. Endothelial cell proliferation and a consistent increase of vascular networks due to angiogenesis have been investigated and found in MS demyelinating lesions only by two groups $[22,23]$ and much remains to be demonstrated about the regulation and significance of angiogenesis in MS.

Increased angiogenesis is a common feature of several neurological conditions, with detrimental effects as observed in Alzheimer's disease (AD) [24], Parkinson's disease (PD) [25] and brain tumours [26], whereas a beneficial effect of angiogenesis has been proposed in cerebrovascular ischemic and traumatic brain injury [27]. In MS lesions and in surrounding normal-appearing white matter (NAWM) and grey matter (NAGM), an angiogenic response has been suggested to contribute to disease progression [28] or, alternatively, to remission after relapses.

Ever since the first descriptions of MS disease signs, the vascular component has been acknowledged as an important element to understand the disease pathogenesis [29-33]; breakdown of the BBB in MS lesions was first described by Broman [34]. Acute and chronic demyelinating lesions and even NAWM of MS patients show blood vessels with a glomeruloid morphology [35], class II MHC antigen expression, intramural fibrin, hemosiderin, and collagen deposition, vessel wall hyalinization, evidence of thrombi and haemorrhages and iron accumulation [36], all features consistent with angiogenesis and endothelial cell proliferation [23,37].

One explanation of the angiogenic response seen in NAWM may be an effect of the increased energy demand for impulse conduction along excitable demyelinated axons, together with a reduced axonal ATP production due to mitochondrial dysfunction, both inducing a chronic state of 'virtual' hypoxia in chronically demyelinated axons [38]. Meanwhile, chronic inflammation itself is pro-angiogenic and, in turn, VEGF is a pro-inflammatory factor.

\section{Angiogenesis in EAE}

A good animal model for MS is experimental allergic encephalomyelitis (EAE). It can be induced by immunization using antigens derived from myelin. These antigens elicit an acute demyelinating process driven by $\mathrm{T}$ cells and macrophages which can have a chronic relapsing course quite similar to MS. Several reports indicate early BBB breakdown in the CNS of EAE [39-44]. Increased vessel density has been documented in different experimental models, including EAE induced in the mouse $[40,45,46]$, guinea pig [47-49], and Lewis rat during the relapse phase [50]. Figure 1 shows our results on EAE induced by $\mathrm{MOG}_{(35-55)}$ immunization in $\mathrm{C} 57 \mathrm{Bl} / 6 \mathrm{~J}$ cerebral cortex vasculature, demonstrating an increased angiogenesis (cumulative vessel length) as compared to control mice.

Boroujerdi and co-worker [40] demonstrated that vascular remodelling is an early process in MOG-induced EAE, because increased vessel areas and endothelial proliferation appeared evident as early as 4 days post-immunization (dpi), in a pre-symptomatic disease phase, while the onset

Table 1 Reported angiogenesis-related changes in serum, CSF and PBMCs of MS patients

\begin{tabular}{|c|c|c|c|c|c|c|}
\hline \multirow{2}{*}{$\frac{\text { Angiogenesis related molecules }}{\text { VEGF-A }}$} & \multicolumn{2}{|c|}{ Serum } & \multicolumn{2}{|c|}{ CSF } & \multicolumn{2}{|c|}{ PBMCs } \\
\hline & $\uparrow$ & {$[12,59,255]$} & $\downarrow$ & {$[53,63]$} & $\downarrow$ & {$[59,63]$} \\
\hline VEGF-D & $\uparrow$ & {$[256]$} & & & & \\
\hline VEGF-R3 & $\uparrow$ & {$[256]$} & & & & \\
\hline Angiopoietin-2 & $\uparrow$ & {$[256]$} & & & & \\
\hline Basic FGF & $\uparrow$ & {$[12]$} & $\uparrow$ & {$[257]$} & & \\
\hline Endothelin-1 & $\uparrow$ & {$[85,184]$} & $\uparrow$ & [185] & $\uparrow$ & {$[258]$} \\
\hline Nitric oxide and NOS & $\uparrow$ & [259] & $\uparrow$ & {$[111,185]$} & $\uparrow$ & [260] \\
\hline TNF-a & $\uparrow$ & {$[261]$} & $\uparrow$ & {$[258,262,263]$} & $\uparrow$ & [264-266] \\
\hline \multirow[t]{2}{*}{ TGF- $\beta$} & $\uparrow$ & {$[267]$} & $\uparrow$ & {$[268]$} & $\downarrow$ & [269] \\
\hline & $\downarrow$ & {$[268]$} & & & & \\
\hline $\mathrm{IFN}-\gamma$ & $\uparrow$ & {$[270]$} & $\uparrow$ & {$[75]$} & $\uparrow$ & {$[265,269]$} \\
\hline MMP-2 & $\uparrow$ & {$[271]$} & $\uparrow$ & {$[272]$} & $\uparrow$ & [273] \\
\hline MMP-9 & $\uparrow$ & {$[271,274]$} & $\uparrow$ & {$[275,276]$} & $\uparrow$ & [273] \\
\hline TIMP-1 & $\uparrow$ & {$[274]$} & $\downarrow$ & {$[277]$} & $\downarrow$ & [278] \\
\hline sCD146 & & & $\uparrow$ & [279] & & \\
\hline
\end{tabular}



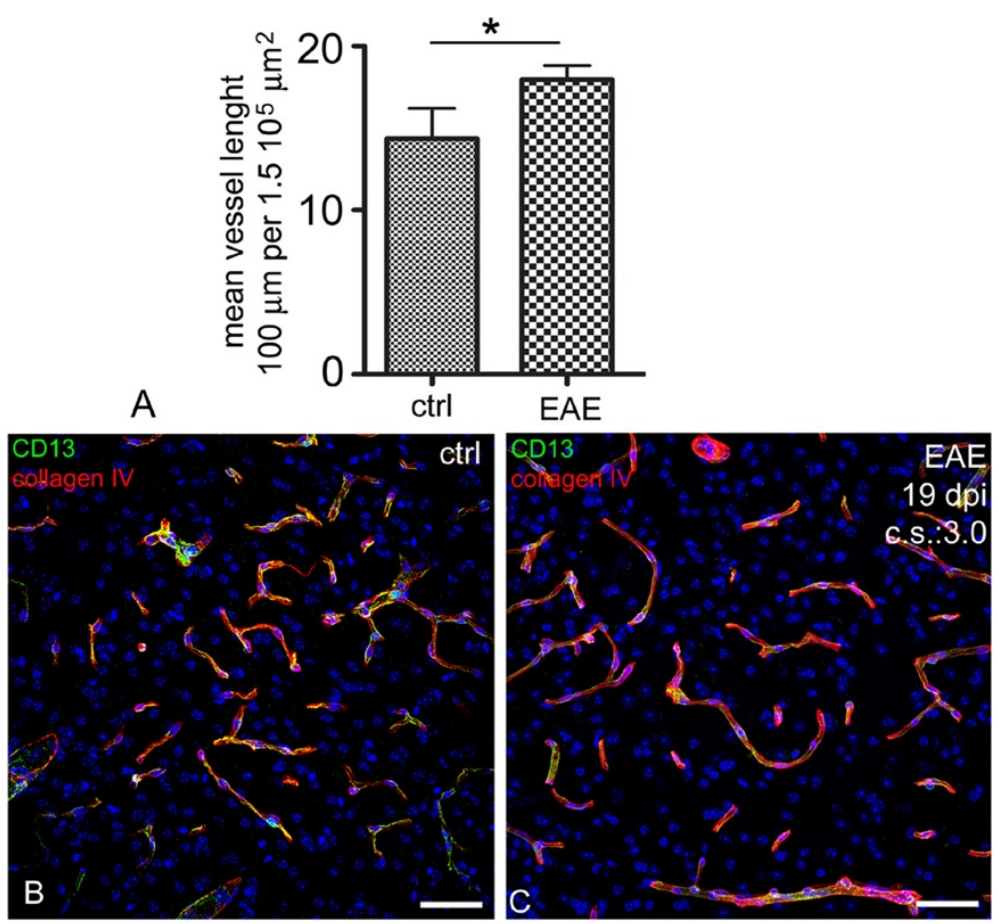

Figure 1 Vessel density is increased in EAE mice. A. Vessel density, calculated as the cumulative vessel profile length per standard area (ImageJ software, $\mathrm{NIH}$, Bethesda, USA; observer blinded to section ranking: CC), is significantly increased in EAE brains at 19 days postimmunization (dpi) (ctrl: 12 week-old control mice, $n=5$; EAE: 12 week-old EAE mice, $n=5$; t-test, $p=0.0026$ ). B, C. Representative images of the vasculature of the same cerebral cortex area (area frontalis) in healthy mice and EAE (mouse at $19 \mathrm{dpi}$ after $200 \mu \mathrm{g}$ of MOG $35-55$ immunization; clinical onset: $10 \mathrm{dpi}$, clinical score $(\mathrm{cs})$ at $19 \mathrm{dpi}=3.0)$ are immunolabelled with CD13, a pericyte marker, and collagen IV of the vessel basal lamina. Some glomeruloid microvessels associated with a high number of pericytes are visible in the EAE brains.

of symptoms occurred around $14 \mathrm{dpi}$. In the EAE, VEGF is expressed by astrocytes, monocytes and activated Th1 lymphocytes, all contributing to BBB breakdown [35,39,51]. Other studies have confirmed increased angiogenesis, severe inflammation and activated VEGF signalling in inflamed lesions [35,46,47,50,52]. VEGF increases inflammation in those areas injected with exogenous VEGF in MBP-immunized animals [35]. In addition, the expression of VEGF is demonstrated in dorsal root ganglion neurons and dorsal column axons in spinal cord, implying that it may act as a neuromodulator [45]. During EAE, an increased neuronal VEGF expression has been described in the early phase but decreased expression in the late phase [45]. Another study reported a decreased VEGF level not only in neurons but also in astroglia in a rat EAE experimental model [53]. A VEGF decrease may be caused by neuronal dysfunction, as already demonstrated in epilepsy by McCloskey et al. [54]. Astroglial production of VEGF is enhanced in pathological conditions, including human astrocytoma [55] and MS and EAE, to promote angiogenesis and glial survival [50]. The striking differences of VEGF expression levels and cell sources among different studies could be explained by the use of different EAE models as regards immunization protocol, animal species and strain employed.

\section{The role of VEGF in MS pathogenesis}

Accumulating evidence indicates a role for VEGF in the pathogenesis of MS. VEGF-A, mainly secreted by astrocytes and neurons but also by cerebral endothelial cells and leukocytes, binds its receptors, VEGF-R1 and VEGF-R2, expressed on different cell types including endothelial cells, astrocytes, neurons, microglia, leukocytes $[19,39,45,47,50,53,56,57]$. An elevated VEGF expression was detected in reactive astrocytes of both active and inactive chronic demyelinated lesions [35], in NAWM from post mortem MS brains [58], and in sera of MS patients during clinical disease relapses [59], and is correlated with the length of spinal cord lesions [12].

VEGF, acting as a pro-inflammatory factor, can cause CNS injury. The effect of VEGF in other disease models could also shed light on the MS pathogenesis. In an ischemia-reperfusion model, inhibiting the activity of endogenous VEGF reduces the size of lesions [60], whereas exogenous administration of VEGF exacerbates CNS injury $[35,57,61]$. However, in experimental conditions, the administration of VEGF to the CNS can be beneficial or detrimental depending on the rat strain, VEGF dose and, especially, timing [61,62].

In the late MS phase, VEGF-A, acting as a neuroprotective agent for neurons and neural progenitors, is 
decreased in the cerebrospinal fluid (CSF) of MS patients and also in peripheral blood mononuclear cells (PBMC) from secondary progressive MS (SP-MS) patients $[53,63]$. In addition, reduced levels of VEGF are associated with EAE, as already mentioned [45,53,64], and also with amyotrophic lateral sclerosis (ALS), a human neurodegenerative disease [65-67].

VEGF is released for neuroprotection purposes, enhances axonal growth and neuronal resistance to injury of cultured neurons [68], but at the same time it induces the dismantling of BBB tight junctions [69].

VEGF-A is mitogenic for astrocytes [70], and reactive astrocytes play a pivotal role in the healing process after spinal cord injury [71]. VEGF-R1 and R2 are upregulated on microglia and other antigen presenting cells after CNS trauma, suggesting a modulating role of VEGF in CNS immune surveillance [72].

VEGF induces anti-inflammatory effects and downregulation of a broad set of inflammatory cytokines and chemokines in microglia/macrophages, and this immunosuppression is linked to the plasticity-promoting action of VEGF [73]. But VEGF-A also recruits monocytes via VEGF-R1, inducing inflammation and BBB breakdown in rat brain [19], as well as being chemotactic for T-cells and macrophages [74]. T cells express VEGF and VEGF-R2, fostering the transition toward the Th1 phenotype; an upregulation of Th1 lymphocytes in CSF has been observed in relapsing MS patients [75]. VEGF-stimulated T cells also exacerbated adoptive EAE in rats [51].

VEGF production is promoted by several proinflammatory cytokines such as IL-1 $\beta$, IL- $1 \alpha$ and IL-18 [76], and macrophages, too, are known to produce VEGF [27] and NO, further stimulating VEGF production and VEGF receptor expression by endothelial cells [36].

VEGF-R2 is also expressed on endothelial cells in active MS lesions [50], possibly contributing to produce an increased vessel density and endothelial proliferation. In response to VEGF, activated endothelial cells down-regulate Cx43 gap junctional communication [77] and increase the expression of cell adhesion molecules such as PECAM-1/ CD31, VCAM, ICAM-1, MIP-1 $\alpha$, MHC I and II, Selectin [19], activating a loop that boosts neuroinflammation and angiogenesis. Thus, the surprisingly multiple effects of VEGF in CNS can be reconciled, considering that VEGF splice variants could result in opposite effects due either to binding with different affinity VEGF-Rs and Neuropilin-1 or to differential tyrosine residue phosphorylation of VEGFRs $[78,79]$.

\section{Other angiogenic molecules potentially involved in MS and EAE angiogenesis}

Hypoxia inducible factor (HIF-1 $\alpha$ ) dimerizes with HIF$1 \beta$ and the complex translocation to the nucleus promotes VEGF transcription [80]. The VEGF-A gene contains a hypoxia responsive element that binds HIF$1 \alpha$ [80]. An increased expression of HIF-1 $\alpha$ was demonstrated in MS lesions showing histopathological features of hypoxic tissue damage [81]. HIF-1 $\alpha$ is also increased in EAE mice, together with other genes involved in cell migration across the BBB [46].

Platelet-derived growth factor (PDGF) and basic fibroblast growth factor (bFGF) contribute to angiogenesis [82] and oligodendrocyte progenitor growth and differentiation after demyelination [83]. Serum levels of bFGF were significantly increased in MS patients, while PDGF showed no significant change [12].

Inflammatory molecules found in MS, including IFN$\gamma$ and TNF- $\alpha$, are also pro-angiogenic factors [84]. Endothelin-1 (ET-1) is another pro-angiogenic factor that is significantly elevated in MS patients [85], and antagonizing the ET-1 receptor ameliorates acute EAE [86]. Angiopoietin-2 (Ang-2) is increased in neurons, glia and inflammatory cells during EAE $[45,64]$. Endothelial $\alpha 5 \beta 1$ integrin, involved in endothelial proliferation in hypoxic conditions [87], is transiently upregulated in EAE [40]. Gene expression analysis of the lasercaptured microvascular compartment of active lesions from MS autopsy samples has shown an increased expression of matrix metalloprotease-14 (MMP-14), MMP-2, ADAM17, VEGF-A, and VEGF-R1 [88]. Other inflammatory mediators such as TNF- $\alpha$, IL-8, transforming growth factor- $\beta$ (TGF- $\beta$ ), and MMP-9 released by immune cells induce angiogenesis [51] and, in turn, new vessel walls are easily permeable to immune cell transmigration and foster adhesion and cytokine molecules expression [89].

\section{Overlapping signalling mechanisms among angiogenesis and neurogenesis, plasticity and repair}

Compelling evidence shows a coordinated interaction between the nervous and the vascular systems during development and in adult brain [90]. This interaction is responsible for the creation of a specialized perivascular microenviroment called the neurovascular niche, in which neural and glial progenitors develop, proliferate and differentiate. Adult neurogenesis primarily occurs in the subgranular zone (SGZ) in the hippocampus and the subventricular zone (SVZ) of the anterior horn of lateral ventricles. During regeneration, as well as during development, angiogenesis and neurogenesis are closely related; the molecular mediators of neurogenesis and angiogenesis overlap and cell-cell signalling between brain endothelium and neural precursors sustains ongoing angiogenesis and neurogenesis [91,92]. This crosstalk is mediated by soluble signals secreted mainly by endothelial cells $[93,94]$. These molecules, affecting both neural and vascular function, have been called 
'angioneurins' [95], classified as angiogenic molecules, morphogens and growth factors; in the latter group the prototypical factor is VEGF. Endogenous VEGF, abundantly secreted by the ventricular neuroepithelium, regulates neural progenitor proliferation, migration, differentiation and the composition of neurons [96]. In adulthood, VEGF signals transmitted by VEGF-R2 and R3 enhance cell proliferation in the SVZ and SGZ by induction after voluntary motor activity [97]. Several findings implicate VEGF as a neuronal survival factor via VEGF-R1 signalling [98], and also a factor promoting oligodendrocyte precursor cell (OPC) survival and migration during axon guidance, thanks to VEGF-R2 and R3 expression [99]. Both angiogenic and neurogenic responses to VEGF are attenuated in the aged mouse brain [100]. Finally, VEGF may impact neuro-vascular interactions through alterations of the extracellular matrix molecule (ECM) composition, particularly of integrins and their ligands [101] and of SDF1/ CXCR4 expression [102]. This ligand/receptor interaction is critically involved in OPC differentiation and remyelination in a model of toxic demyelination [103]. The ECM of vascular endothelial cells can trap FGF-2 (bFGF), which facilitates neurogenesis [104] and promotes OPC migration to demyelinated lesions [105]. Epidermal growth factor (EGF), pigment epithelium-derived factor (PEDF) and TGF- $\alpha$ have been implicated in adult neurogenesis and oligodendrogenesis $[95,106]$. EGF and FGF receptors coactivation is required for the maintenance of neural stem cells (NSCs) and progenitor cells in the adult SVZ $[107,108]$. However, prolonged exposure to EGF induces oxidative neuronal death and astrocyte commitment from NSCs [109] and a higher secretion of EGF has been demonstrated in PBMCs of patients with relapsing remitting MS (RR-MS) [110]. Neurotrophins such as nerve growth factor (NGF) and brain-derived neurotrophic factor (BDNF) reciprocally promote angiogenesis [111,112], and higher amounts of both have been detected in CSF from MS patients [113,114]. BDNF and its receptor tyrosine kinase (gp145trkB) have been involved in immune-mediated neuroprotection in MS lesions $[115,116]$. In other situations, vessels act as guidance templates for axons, releasing guidance cues such as VEGF, artemin, neurotrophin-3 or ET-3 [117].

VEGF-Rs cooperate with the Notch pathway during vascular patterning and also neurogenesis [118]. Notch1 and Notch-4 receptors, as well as Jagged-1, delta like 1 (Dll-1), and Dll-4 ligands of Notch, are expressed in endothelial cells [119]. In adult brain, the Notch pathway is expressed in SVZ and SGZ NSCs and regulates the maintenance of an undifferentiated state [120]. In addition, Notch-expressing NSCs are closely juxtaposed to local blood vessels, and able to directly bind Dll-4 and Jagged-1 exposed on the endothelial cells, where a decreased pericyte coverage exists [121]. MS demyelinated lesions contain Notch-expressing OPCs and modulation of the Notch pathway in EAE enhances remyelination and clinical recovery [122].

Wnt/ß-catenin and Sonic HedgeHog (SHH) morphogen signallings both regulate embryonic neurogenesis and angiogenesis $[123,124]$ and are variably associated with the remyelination process [125] and BBB integrity [126]. Nogo-A is an axonal growth inhibitor, and negative regulator of CNS angiogenesis [127]; anti-Nogo IgGs have been shown to suppress EAE through an immunomodulatory activity and the removal of remyelination obstacles between axons and new myelinating membranes [128].

Netrin-1 is a matrix-bound molecule interacting with different receptors (UNC and DCC, certain integrins, DSCAM - Down's syndrome cell adhesion molecule and adenosine receptor AR2b) involved in axon guidance and angiogenic blood vessel guidance [reviewed in 91], that has been shown to inhibit migration of oligodendrocyte precursor cells into the demyelinated lesions [129]. Ephrins and their Eph receptors are short range axon guidance molecules, expressed in developing vessels and critical for their maintenance [reviewed in 91], that have shown different expression profiles in several CNS cytotypes of MS patients [130]. The specific receptor EphA4 has been implicated in the onset and a more severe course of EAE, probably due to increased axon damage during demyelination [131]. Also semaphorins and their receptors, plexins and neuropilins, regulate both axon guidance and angiogenic vessel branching and extension [reviewed in 91], and are crucially involved in remyelination failure in MS $[132,133]$, dysregulation of $\mathrm{T}$ cell responses and the maintenance of tolerance in EAE [134,135].

Ang- 1 and -2 also play an angiogenic role, together with VEGF, during blood vessel formation and stimulate proliferation and migration of neural precursor cells (NPCs) [90,136]. The expression level of Ang-2 is increased in RR-MS patients sera (Table 1) and in EAE mice spinal cord [45,64].

Erythropoietin (EPO) promotes angiogenesis, VEGF secretion and VEGF-R2 expression on the cerebral endothelium and also CNS neurogenesis, directly via the EPO receptor and indirectly via BDNF-increased secretion and/ or suppression of cytokine signalling [137]. The relevant neuroprotective, proangiogenic and anti-inflammatory potential of EPO in MS/EAE is discussed below. In addition, oestrogen and androgen promote angiogenesis and neurogenesis after CNS injury $[138,139]$. EAE studies with various sexual hormones or estrogen receptor (ER) ligand treatments led to clinical disease protection, as well as protection against CNS inflammation, demyelination and axonal loss [reviewed in 138]. ER $\beta$ ligand may not only prevent demyelination, but also promote remyelination [140]. In a pathological situation (stroke), nitric oxide (NO) has a dual role in promoting angiogenesis and 
neurogenesis [141,142] and its action is closely linked to VEGF and BDNF expression in endothelial cells [143].

Recent studies have revealed that a hypoxic gradient is an adequate stimulus to foster angiogenesis and neurogenesis, upregulating HIF-1 [144]. Somatic stem cells reside within hypoxic niches, where low oxygen prevents oxidative stress and premature differentiation [145]. Moreover, NSCs have been observed to migrate to brain regions where active angiogenesis is occurring in neurological diseases [90], creating a temporary vascular niche where the angiogenesis and neuroreparative processes are reciprocally fostered [146].

In the context of mutual relationships between different cells of the neurovascular unit, endothelial cells of microvessels have shown to provide trophic support for OPCs [147]. During development, OPCs migrate from the ventricular zone to their destination and then differentiate into myelinating oligodendrocytes. OPCs are also widely distributed in adult human brain and MS lesions [148] and are guided to repair demyelinated axons [149]. Endothelial cells actively support the maintenance of OPCs, acting directly through endothelin B receptors expressed by OPCs [150]. Several growth factors, such as PDGF- $\alpha$, bFGF, hepatocyte growth factor (HGF), are known to induce proliferation and differentiation of OPCs, but VEGF produced by cerebral endothelial cells has a unique migration-promoting effect on OPCs [99]. Thus, VEGF is a biphasic mediator in the neurovascular response to demyelinating injury; during the early inflammatory phase it promotes BBB permeability, and in the chronic phase, accelerates not only angiogenesis, neurogenesis but also oligodendrocyte lineage plasticity and repair. In fact, exposure of endothelial cells to sublethal levels of oxidative stress abrogates their support of OPC viability [147] and this could explain why OPC differentiation into myelinating oligodendrocytes seems to be blocked or ineffective in MS. Additionally, in response to injury, activated astrocytes release bursts of ATP and induce hypertrophy of their vascular endfeet [137]. This locally increased ATP and decreased oxygen potentiates NSC expansion by upregulating VEGF, EGF, FGF-2 and NO [151] but delaying differentiation. Angiocentric perivascular demyelinated lesions show local inflammation also in the proximity of the lateral ventricles SVZ, and the effects of released inflammatory mediators on the neurovascular niches may be profound in this area, that is one of the preferential locations of demyelinating inflammatory lesions in MS [152]. Persistent brain inflammation, induced by immune cells targeting myelin, extensively alters the proliferative and migratory properties of SVZ-resident stem cells (NPCs and OPCs) [153,154], and could justify the limited repair mechanisms observed after a long disease duration in MS patients (Figure 2). In addition, MS CSF contains a panoply of humoral signals that could interfere with the ependymal cells and consequently the subependymal neurogenic cells [155].

\section{Chronic hypoperfusion, hypoxia and angiogenesis}

Positron Emission Tomography (PET) and Single Photon Emission Computed Tomography (SPECT) studies have shown a decreased cerebral blood flow (CBF) in grey and white matter of MS patients [156,157]. Non conventional magnetic resonance (MR) techniques, such as proton MR spectroscopy and magnetization transfer resonance, have demonstrated diffuse pathological changes affecting both NAWM and NAGM in MS patients. Perfusion weighted imaging showed a significant $\mathrm{CBF}$ reduction and prolonged transit time throughout the NAWM of a group of RR-MS patients [158], and also involving NAGM [159]. Furthermore, CBF and cerebral blood volume (CBV) were reduced in primary progressive (PP-MS) patients $[160,161]$. A decreased blood flow has been speculatively proposed as a cause of leukocyte infiltration crossing the venule wall of WM [162] but CNS hypoperfusion could actually be a consequence of disease progression.

Acute lesions visible as local gd.e. areas on T1 weighted MRI were characterized by increased CBF and CBV $[163,164]$. However, more evolved MR parameters for nervous tissue angiogenesis such as time-dependent changes in $1 / T_{1}\left(R_{1}\right)$, used to form maps of blood-to-brain transfer constant of Gd-DTPA $\left(\mathrm{K}_{\mathrm{i}}\right)$, ICAM-1 micron-sized particles of iron oxides, in addition to magnetization transfer parameters such as $\mathrm{T}_{1 \text { sat }}$ and $\mathrm{k}_{\mathrm{inv}}$ [165], could be used to further investigate MS angiogenesis in vivo. Our opinion is that $\mathrm{BBB}$ incompetence, demonstrated by gd.e., could reveal the same MRI sign both in early, immature angiogenic microvessels and in inflamed venules. In fact, possible evidence of the presence of angiogenesis in MS could be the appearance of "ring enhancement" at the periphery, but not in the centre, of chronic active lesions during contrast-enhanced MRI [166]. Nevertheless, ring enhancing lesions are unusual in progressive MS and, in general, gd.e. is able to detect venular BBB incompetence in acute MS lesions containing both early angiogenic vessels and infiltration of immune cells.

Chronic lesions and the remaining NAWM and NAGM appeared hypoperfused due to a reduced axonal activity [167], with a lower $\mathrm{K}^{+}$release in the periaxonal and perivascular space, reduced astrocyte metabolism [168] and reduced arteriolar vasodilatation [169] (Figure 2C). In this context it is not surprising to find elevated VEGF signalling [58], increased vessel density and angiogenic endothelial cells in MS chronic demyelinated lesions and NAWM [22] as a frustrated attempt to overcome the chronic hypoperfusion.

In short, angiogenesis and an increased vascular blood flow could dominate the early inflammatory phase of lesion formation, whereas, despite an increased vessel 


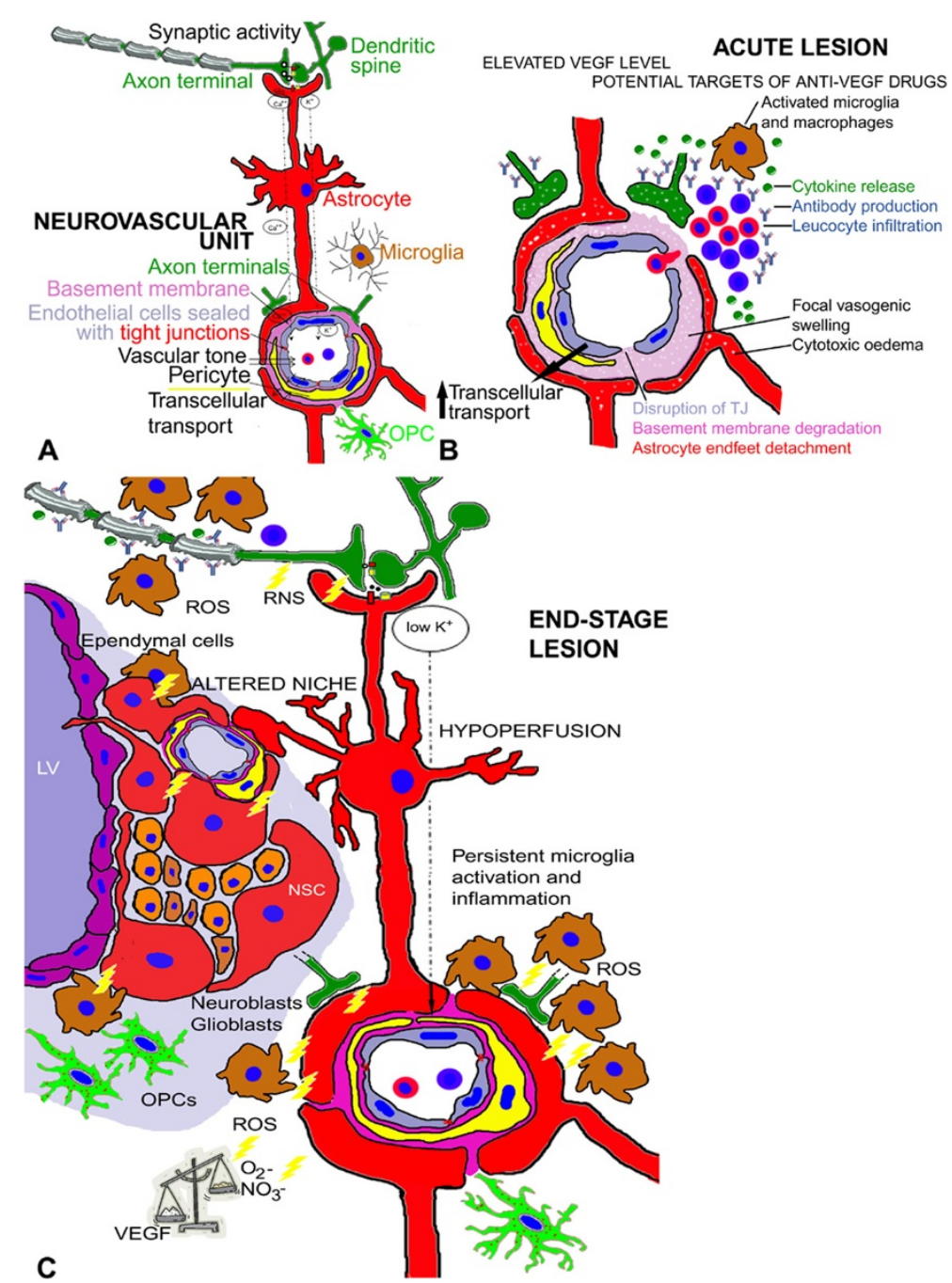

Figure 2 Hypothetical model of Neurovascular Unit function (NVU) (A) and dysfunction in an acute MS lesion (B) and a chronic endstage lesion (C). (A) Composition of blood-brain barrier (BBB)-provided microvessels, formed by endothelial cells which are connected by tight junctions (TJ), pericytes, astrocyte endfeet, and a continuous layer of basement membrane (BM). Neurovascular coupling is brought about by astrocyte processes which remove excess $\mathrm{K}^{+}$ions at active synaptic spaces and release these ions into perivascular spaces; at the same time Glutamate (Glu) bound to astrocyte receptors can increase astrocytic $\mathrm{Ca}^{++}$levels and produce vasodilatatory substances. Microglia and oligodendrocyte precursor cells (OPCs) contribute to NVU function. (B) An acute MS lesion, dominated by high levels of VEGF and other angiogenic molecules, shows BBB leakiness, vasogenic swelling of BM and disrupted NVU interactions: claudin-5 and occludin, two TJ proteins, are mislocalized and downregulated; the BM is degraded by MMPs, mainly released by leukocytes infiltrating vessel BM; microglia are activated and release large amounts of pro-inflammatory mediators; astrocyte endfeet are detached from pericytes. Activated B lymphocytes release self-targeted antibodies damaging myelinated axons. (C) Chronic end-stage MS lesion dominated by hypoperfusion, and persistence of an inflammatory milieu with abundant reactive oxygen species (ROS), peroxynitrite (RNS) and stress-associated proteins, all together inhibiting the net pro-angiogenic activity. The drawing shows pro-inflammatory microglia and also the influence of demyelination on reduced axonal activities, decreased vasodilatatory stimuli and consequent vasoconstriction. Hypoperfusion is also due to vessel wall hyalinization, collagen deposition and astrocyte endfeet hypertrophy. Persistent inflammation is also responsible for endothelial-derived protective molecules and growth factors downregulation which, in turn, maintains neural stem cells (NSC) in a resting state and impedes neuroblast and OPC maturation in the neurovascular niches in the subependymal layer of the lateral ventricle (LV) and in other neuroregenerative sites around blood microvessels.

density, hypoperfusion could characterize the late degenerative phase, featuring a limited efficiency of endogenous neuroprotective mechanisms, by which angiogenesis, increased cerebral blood flow and neurorepair should be further promoted. This notion could be extended, since raised perfusion was higher in the WM of RR-MS at onset, before therapy, whereas hypoperfusion was more prominent in the PP-MS group [161], consistently associated with axonal loss, minor inflammatory signs and resistance to the available immunomodulatory drugs [170].

The role of hypoxia in inflammatory lesions of both MS and EAE may be compound, since chronic mild hypoxia 
$\left(10 \% \mathrm{O}_{2}\right)$ has a beneficial effect in the acute and chronic phases in MOG-induced mouse EAE [171]. This effect is due to the promotion of tissue survival but also to the modulation of immune mechanisms: pericytes produce anti-inflammatory eicosanoid prostaglandin D2, endothelial cells release TGF- $\beta$ that promotes the differentiation of $\mathrm{T}$ regulatory cells, and astrocytes express HIF-1 $\alpha$ [172]. One of the most consistent differences in gene expression between secondary progressive (SP-MS) patients and healthy controls was enhancement of HIF- $1 \alpha$ and its downstream components [58]. In this specific inflammatory condition, the increased effort of HIF- $1 \alpha$ and VEGF promoting angiogenesis/arteriogenesis and normalizing oxygen levels to maintain oligodendrocyte and neuron functions could be counterbalanced by other molecules, such as reactive oxygen species (ROS) [173-175], nitric oxide intermediates and peroxynitrite (RNS) [176]. These molecules could be responsible for mitochondrial dysfunction [173], distal oligodendropathy [177], apoptotic-like cell death and axonal injury [178]. In MS patients, these pathologic mechanisms are associated with astrocyte dysfunction [167-169], which could explain the arteriolar vasoconstriction in the presence of high metabolic demands (neurovascular uncoupling), accounting for so severe a hypoperfusion state as to result in hypoxia, and ultimately responsible for disease progression. In fact, the level of VEGF expression in resident astrocytes and neurons appears increased in progressive MS patients $[35,58]$, as well as in RR-MS [35], and a reduced level of VEGF has been detected only in non-resident mononuclear cells in CSF and peripheral blood [53,63]. This latter evidence could be compatible with the hypothesis of a true histotoxic hypoxia, as well as the observed lactate increase in CSF and serum of MS patients $[179,180]$. Another important pathogenic aspect of chronic progressive MS could be mitochondrial dysfunction, aggravating the nervous tissue distress caused by hypoxic injury [177]. Inflammatory cells (especially macrophages and activated microglia) releasing ROS and RNS $[173,176,181]$ provoke clonally expanded mitochondrial DNA deletions responsible for respiratory chain defects detected in MS patients [182,183] and a consequently inevitably decreased ATP synthesis.

Finally, cerebral hypoperfusion in MS patients might be aggravated by ET-1 $[85,184,185]$, together with alterations in the renin-angiotensin-aldosterone-system detected in MS patients such as decreased CSF angiotensin II levels [186], increased serum angiotensinogen converting enzyme [187] and up-regulation of angiotensin II receptor type I on myelin-autoreactive $\mathrm{CD} 4^{+} \mathrm{T}$ cells and monocytes of MS brain lesions [188].

\section{Therapeutic potential of targeting angiogenesis}

Although angiogenesis is likely not the first event in the pathogenesis of MS, its changing role in the different phases of disease progression makes it an important and underestimated target in therapeutic options. The current concept of the natural history of MS refers to a combination of two phenomena underlying the two phases of MS, namely an inflammatory process in the remitting phase and a neurodegenerative process in the progressive phase. The secondary progressive phase of MS is primarily caused by axonal degeneration following demyelination. The potential advantages of inhibiting angiogenesis in the early phase of MS could stem from reducing the vascular supply of nutrients and inflammatory cells to the demyelinating lesions, halting the production of endothelialderived pro-inflammatory molecules [189]. This approach could be proposed only in aggressive acute relapsing MS, where immunosuppression could be associated with specific antiangiogenic therapy. Considering the central role of VEGF signalling in pathological angiogenesis during the early MS phase, anti-VEGF therapy should be highly beneficial in the aggressive MS-subtype. We will briefly discuss some of these strategies, but do not propose to provide an exhaustive review of the literature.

Bevacizumab, a monoclonal anti-VEGF antibody approved for renal, ovarian, lung and mammary glands malignancies, that has been proven to ameliorate EAE [64], is now being tested in a clinical trial in a group of patients with neuromyelitis optica, an aggressive disease mimicking MS (ClinicalTrials.gov Identifier: NCT01777412). Nevertheless, experimental inhibition of VEGF signalling using another neutralizing antibody decreased angiogenesis and astroglial proliferation, but led to greater neurodegeneration in a model of stab wound injury of the CNS [190]. In murine MOG-EAE, antagonizing VEGF-R2 with Semaxinib (SU5416) was effective only in the acute inflammatory phase of the disease, but not in the chronic, degenerative phase [46]. In addition, Bouerat et al. [191] demonstrated a high efficacy of several anti-VEGF-R2 analogues and pro-drugs in an EAE model. Systemic administration of cavtratin, a selective eNOS inhibitor that can abrogate VEGF signalling, reverted neurologic deficits in EAE mice [39].

Bortezomib, a proteasome inhibitor, could be useful to treat MS considering its potent anti-lymphocytic and antiangiogenic activity [192].

Thalidomide, and its analogue lenalidomide, are known to inhibit TNF- $\alpha$, VEGF and IL- 6 production [193]. Thus, the use of thalidomide in MS has been suggested, considering its protective action against endothelial damage induced by TNF- $\alpha$ [194,195], reduced leukocyte chemotaxis and phagocyte activity [196], inhibition of IFN- $\gamma$ and IL-12 [197], co-stimulation of CD8+ lymphocytes [198]. Thalidomide has been demonstrated to restore $\mathrm{BBB}$ tightness and to protect the CNS in two experimental models of brain toxicity [199]. In the MOG-induced EAE model, N-(aminopropyl)-4- 
amino thalidomide is a promising therapeutic tool, able to reverse clinical and histological signs of EAE [36,200].

Corticosteroids stabilize the BBB [201] and inhibit angiogenesis in tumours [202] and chronic inflammation [203] (Table 2).

IFN- $\beta$ displays anti-angiogenic and $\mathrm{BBB}$ stabilizing properties [84,204,205]. Glatiramer Acetate (GA; copolymer 1), a mixture of synthetic peptides mimicking myelin basic protein, used as a first-line treatment option for RRMS, inhibits a tryptophanyl-tRNA synthetase known to modulate angiogenic signalling [206,207]. The selective adhesion molecule inhibitor Natalizumab, which binds integrin- $\alpha 4$ on endothelial cells and blocks the VCAM-1 driven transmigration of immune cells sensitized against myelin antigen from the vessel lumen to the neuropil across the $\mathrm{BBB}$, precludes VEGF-induced angiogenesis $[208,209]$. Fingolimod (FTY720), an immunomodulator that acts on sphingosine 1-phosphate (S1P) receptors, is the first oral drug approved for the treatment of RR-MS. Downmodulation of S1P receptor type 1 (S1P1) prevents the release of lymphocytes from lymph nodes into the lymphatic vessels and vascular recirculation to the CNS, reduces astrogliosis, restores $\mathrm{BBB}$ function, and inhibits angiogenesis during chronic neuroinflammation, also via inhibiting PDGF-B-induced migration of vascular smooth muscle cells [210-212]. Alemtuzumab, recently licensed for the treatment of MS, is a humanized monoclonal antibody directed against CD52, a protein that is widely distributed on the surface of lymphocytes and monocytes and is

Table 2 Currently used disease-modifying agents and acute exacerbation medications with an anti-angiogenic property

\begin{tabular}{lll}
\hline Chemical name & Brand name & $\begin{array}{l}\text { References related to } \\
\text { anti-angiogenic activity }\end{array}$ \\
\hline Alemtuzumab $^{1}$ & Lemtrada & {$[213]$} \\
Cyclophosphamide $^{2}$ & $\begin{array}{l}\text { Endoxan, Cytoxan, } \\
\text { Neosar, Procytox, } \\
\text { Revimmune }\end{array}$ & {$[217]$} \\
Dexamethasone & Decadron & {$[203]$} \\
Methylprednisolone & Solu-Medrol & {$[203]$} \\
Dimethyl fumarate & Tecfidera & {$[215]$} \\
Fingolimod & Gilenya & {$[210-212]$} \\
Glatiramer acetate & Copaxone & {$[206,207]$} \\
Interferon $\beta-1 a$ & Avonex, Rebif & {$[84,204,205]$} \\
Interferon $\beta-1 b$ & Betaferon, Extavia & \\
Mitoxantrone & Novantrone & {$[216]$} \\
Natalizumab & Tysabri & {$[208,209]$} \\
Teriflunomide & Aubagio & $\begin{array}{l}\text { Only indirect evidence } \\
\text { derived from anti- } \\
\text { lymphocytes activity }\end{array}$ \\
\hline
\end{tabular}

${ }^{1}$ licensed for MS therapy by the European Medicine Agency (EMA) but rejected by the Food and Drugs Administration (FDA), USA; ${ }^{2}$ not licensed but used in clinical practice. also an anti-angiogenic molecule [213]. Teriflunomide, an inhibitor of the mitochondrial enzyme dihydroorotate dehydrogenase, which is critically involved in pyrimidine synthesis, inhibits immune cell proliferation but shows only an indirect antiangiogenic activity. Dimethyl fumarate is the active compound of BG-12, recently licensed for the treatment of RR-MS; its activity is predominantly mediated via activation of the nuclear 1 factor (erythroid-derived 2)-like 2 (Nrf2) antioxidant response pathway [214]. BG-12 also modulates immune-cell responses, suppresses proinflammatory-cytokine production and inhibits angiogenesis [215] (Table 2).

Immunosuppressive therapies (i.e. mitoxantrone, cyclophosphamide), used to revert the aggressive course of MS, also exert an anti-angiogenic activity [216,217]. A chemotherapeutic agent, cladribine, effective but unsafe in MS, decreases the level of angiogenic factors [218]. Mycophenolate mofetil is an immunosuppressive agent, sometimes used as a disease-modifying therapy for MS, that can stabilize aggressive MS patients, and shows an antiangiogenic activity [219]. Minocycline has been effective in EAE [220]; it is an anti-angiogenic drug in tumours [221], decreases VEGF and MMP-9 [222,223] and has been tested in combination with IFN- $\beta$ (NCT01134627) and GA (NCT00203112) [224].

To date, disease modifying drugs have been shown to have little impact on the natural course of the progressive phase of MS. The development of add-on treatments targeting axonal repair and remyelination and/or slowing disease progression through neuroprotection/ neuroregeneration remains the most important goal in the clinical management of chronic progressive MS $[225,226]$. As the endogenous neuroregenerative response can be suppressed by inflammation or exhaustion, delivery of neurovascular factors by mesenchymal, foetal or bone marrow-derived stem cells could increase endogenous repair, angiogenesis, neuronal and axonal survival and oligodendrocyte maturation and myelin synthesis. The multitasking vascular and neuroprotective effects of VEGF show promise for therapeutic use in neurodegenerative disorders such as ALS, PD, AD and, eventually, progressive MS [227-229], when its harmful vascular side effects can be restricted. Intracerebroventricular delivery of recombinant VEGF protein improves motor performance and survival in a rodent model of ALS [230]. In a stroke model, exogenous VEGF administration increases neurogenesis of the SVZ, only after 28 days, without concomitant angiogenesis, demonstrating that a specific VEGF isoform could protect neurons independently of the endothelial cell influence [231]. In the EAE model, despite several reports of an improved clinical score after early VEGF inhibition, one study [232] demonstrated that pertussis toxin stimulated VEGF expression and that VEGF neuroprotection could 
be responsible for milder disease. VEGF may have different effects in different cell types depending on different splice variants [233]. The endogenous splice isoform VEGF- $\mathrm{A}_{165} \mathrm{~b}$ has shown a potent neuroprotective effect in hippocampal and cerebro-cortical neurons (mediated by VEGFR2 and neuropilin-1 co-stimulation) with no propermeability property $[78,234]$. This isoform may be an interesting add-on therapy option against axon damage in progressive MS, with fewer adverse vascular effects. Another interesting approach could be to specifically inhibit vascular permeability without affecting the endogenous neuroprotective effect of VEGF. This approach has been successfully investigated in EAE mice using angiostatin [235], cavtratin [39], anti-microRNA155 [236] and needs to be replicated in humans.

A protective effect of vitamin D on the risk of MS has been demonstrated [237] and several trials suggested beneficial effects of vitamin D supplementation. Vitamin D3 promotes angiogenesis in endothelial cell cultures [238]. Atorvastatin, pravastatin and simvastatin have both anti- and pro-angiogenic activities depending on the dose, specific angiogenic stimulus, and angiogenesis mechanism in the specific disease local microenviroment [239,240]. They have been tested as neurorepair attempts in several randomized clinical trials in combination with IFN $-\beta$ and GA [241-244].

Because neurons, oligodendrocytes and blood vessels are involved in the pathogenesis of MS, it would be better to use the same compound to treat all involved systems. Apart from VEGF, other molecules can stimulate neurogenesis, oligodendrogenesis and angiogenesis. The first is thyroxine (T4), that can decrease EAE severity [245] increase NGF and promote neurogenesis and remyelination. Other potential treatment options in selected MS patients could be sexual hormones added to an immunomodulator [138]. Among potential candidate compounds for neuroprotection/neuroregeneration and angiogenesis modulators in progressive MS, EPO appears very promising. EPO possesses properties that could address several of the pathophysiological mechanisms involved in progressive MS, being an anti-apoptotic and anti-oxidative molecule, promoting neurite outgrowth and axonal repair, neurogenesis, angiogenesis and BBB integrity (reviewed in [246]). In addition, EPO treatment could temporarily decrease iron stores within the CNS, possibly providing an additional beneficial effect in chronic progressive MS patients. Excess iron may have several deleterious effects on axons, including iron-catalyzed production of ROS and RNS causing oxidative tissue injury. Iron accumulation may also alter oligodendrocyte activities (reviewed in [246]). Recombinant human EPO treatment has already proven safe and effective in severely affected MS patients [247-249]. Testing in clinical trials of EPO variants developed to minimize the risk of thromboembolism is a promising research field.

\section{Concluding remarks}

In MS as well as in EAE, CNS lesions and surrounding NAWM/NAGM are characterized by different vascular changes in the different disease phases. In the acute demyelinating phase, there is a complex balance between vessel modulators released by inflammatory cells and hypoxia of more distant nervous tissue from blood microvessels that could be affected by localized vasogenic swelling due to the VEGF-induced altered vascular permeability [250,251]. A reduced axon activity could cause hypoperfusion and hypoxia also in the chronic disease phase (Figure 2).

Blocking VEGF signalling and angiogenesis reduced clinical and pathological signs of disease in the early phase in an animal model of MS [39,46,64,190,191]. EAE model experiments have shown that hypoxic pre-conditioning reduced the clinical severity and leukocyte infiltration thanks to increased levels of VEGF, TGF- $\beta$, IL-10 [171,172]. However, aberrant angiogenesis and localized regression of the microvasculature can contribute to brain hypoperfusion and neurovascular uncoupling [252]. In this context, the timing of vascular remodelling and growth factors release could be crucial. In early demyelinating lesions, remodelling is harmful and exacerbates the disease. Nevertheless, in chronic disease phases, angiogenesis, and especially the neuroprotective properties of VEGF, might be highly beneficial. An alternative therapeutic agent for this neurodegenerative condition with a lesser influence on cell types other than neurons, and also lacking pro-permeability/angiogenic properties, may be VEGF-A ${ }_{165} \mathrm{~b}[78,234]$.

Angiogenesis, induced either by CNS inflammation or by hypoxia, provides trophic factors for tissue remodelling $[91,253]$. In a chronic hypoxia model of cerebrovascular disease, angiogenesis proceeds in the absence of BBB leakage, being associated with increased tight junction protein expression [254]; this demonstrates that angiogenesis is not indissolubly linked to BBB breakdown. In addition, resolution of impeded angiogenesis in neural stem cell niches in the SVZ would increase oxygen levels and could also promote differentiation of oligodendrocyte precursors.

Future therapeutic efforts should be based less on a total block of angiogenesis, and more on titration of the response to produce new vessels with a functional integrity. These therapeutic options could be promising for application in MS, even if the angiogenic component of MS has still to be fully explained. To determine whether there is a correlation between clinical benefit and levels of angiogenic molecules, studies comparing clinical signs and circulating angiogenic markers in treated or untreated MS patients over time are currently ongoing, together with studies exploring angiogenesis-promoting molecules versus antiangiogenic drugs in late stage chronic MOG-induced EAE. In addition, clinical trials exploring combination therapy with an MS subtype-oriented 
immunomodulator/immunosuppressive agent added to an angiogenic/neuroreparative molecule during the progressive phase of MS could be warranted.

\section{Abbreviations}

AD: Alzheimer's disease; ADAM17: Disintegrin and metalloproteinase domain-containing protein 17; ALS: Amyotrophic lateral sclerosis; Ang: Angiopoietin; AR: Adenosine receptor; ATP: Adenosine triphosphate; BBB: Blood-Brain Barrier; BDNF: Brain-derived neurotrophic factor; bFGF: Basic Fibroblast Growth Factor; BM: Basement membrane; Ca: Calcium; CBF: Cerebral blood flow; CBV: Cerebral blood volume; CD: Cluster of differentiation; CNS: Central Nervous System; CS: Clinical score; CSF: Cerebrospinal fluid; ctrl: Control; Cx43: Connexin43; CXCR4: Chemokine (C-X-C motif) receptor 4; DII: Delta like; dpi: Days postimmunization; DSCAM: Down's syndrome cell adhesion molecule; EAE: Experimental allergic encephalomyelitis; ECM: Extacellular matrix molecule; EGF: Epidermal Growth Factor; ENOS: endothelial Nitric Oxide Synthetase; EPO: Erythropoietin; ER: Estrogen receptor; ET: Endothelin; GA: Glatiramer acetate; gd.e.: Gadolinium-DTPA enhancement; Glu: Glutamate; HGF: Hepatocyte Growth Factor; HIF: Hypoxia Inducible Factor; ICAM-1: Intercellular adhesion molecule 1; IFN: Interferon; IgG: Immunoglobulin G; IL: Interleukin; LV: Lateral ventricle; MBP: Myelin basic protein; MHC: Major Histocompatibility Complex; MIP-1a: Macrophage inflammatory proteins 1a; MOG: Myelin Oligodendrocyte Glycoprotein; MRI: Magnetic resonance imaging; MS: Multiple sclerosis; NAGM: Normalappearing grey matter; NAWM: Normal-appearing white matter; NGF: Nerve Growth Factor; NO: Nitric oxide; NPC: Neural precursor cell; Nrf2: Nuclear 1 factor (erythroid-derived 2)-like 2; NSC: Neural stem cells;

NVU: Neurovascular unit; OPC: Oligodendrocyte precursor cell; PBMC: Peripheral blood mononuclear cells; PD: Parkinson's disease; PDGF: Platelet-Derived Growth Factor; PECAM-1: Platelet endothelial cell adhesion molecule-1; PEDF: Pigment Epithelium-Derived Factor; PET: Positron emission tomography; PP-MS: Primary progressive MS patients; RNA: Ribonucleic acid; RNS: Reactive nitrogen species; ROS: Reactive oxygen species; RR-MS: Relapsing remitting MS; S1P: Sphingosine 1-phosphate; SDF1: Stromal cell-Derived Factor 1; SGZ: Subgranular zone; SHH: Sonic HedgeHog; SPECT: Single photon emission computed tomography;

SP-MS: Secondary progressive MS patients; SVZ: Subventricular zone; T4: Thyroxine; TGF: Transforming Growth Factor; TJ: Tight junction; TNF: Tumour necrosis factor; tRNA: transfer ribonucleic acid; VCAM: Vascular cell adhesion protein 1; VEGF: Vascular Endothelial Growth Factor; VEGF-R: Vascular Endothelial Growth Factor Receptor; WM: White matter.

\section{Competing interests}

The authors declare that they have no competing interests.

\section{Authors' contributions}

FG and CC carried out the EAE experiments, the morphometric and statistical analyses; DR and MT conceived of the study. FG, CC, DR and MT drafted the manuscript. All authors read and approved the final manuscript.

\section{Acknowledgements}

Prof. L. Roncali (Department of Basic Medical Sciences, Neurosciences and Sense Organs, University of Bari, Italy) is gratefully acknowledged for her critical review of the article. We thank M.V.C. Pragnell, BA, for linguistic help.

\section{Author details}

${ }^{1}$ Department of Basic Medical Sciences, Neurosciences and Sense Organs, University of Bari 'Aldo Moro', Piazza Giulio Cesare, 11, 70124 Bari, Italy. ${ }^{2}$ National Cancer Institute 'Giovanni Paolo II', via O. Flacco, 65, 70124 Bari, Italy.

Received: 26 May 2014 Accepted: 9 July 2014

Published: 22 July 2014

\section{References}

1. Brück W, Bitsch A, Kolenda H, Brück Y, Stiefel M, Lassmann H (1997) Inflammatory central nervous system demyelination: correlation of magnetic resonance imaging findings with lesion pathology. Ann Neurol 42:783-793
2. Kermode AG, Thompson AJ, Tofts P, MacManus DG, Kendall BE, Kingsley DP, Moseley IF, Rudge P, McDonald WI (1990) Breakdown of the blood-brain barrier precedes symptoms and other MRI signs of new lesions in multiple sclerosis. Pathogenetic and clinical implications. Brain 113:1477-1489

3. Alvarez Jl, Cayrol R, Prat A (2011) Disruption of central nervous system barriers in multiple sclerosis. Biochim Biophys Acta 812:252-264

4. Claudio L, Raine CS, Brosnan CF (1995) Evidence of persistent blood-brain barrier abnormalities in chronic-progressive multiple sclerosis. Acta Neuropathol 90:228-238

5. Kirk J, Plumb J, Mirakhur M, McQuaid S (2003) Tight junctional abnormality in multiple sclerosis white matter affects all calibers of vessel and is associated with blood-brain barrier leakage and active demyelination. J Pathol 201:319-327

6. McQuaid S, Kirk JT (2005) The blood-brain barrier in multiple sclerosis. Int Congress Series 1277:235-243

7. Minagar A, Alexander JS (2003) Blood-brain barrier disruption in multiple sclerosis. Mult Scler 9:540-549

8. Plumb J, McQuaid S, Mirakhur M, Kirk J (2002) Abnormal endothelial tight junctions in active lesions and normal-appearing white matter in multiple sclerosis. Brain Pathol 12:154-169

9. van Horssen J, Bö L, Vos CM, Virtanen I, de Vries HE (2005) Basement membrane proteins in multiple sclerosis-associated inflammatory cuffs: Potential role in influx and transport of leukocytes. J Neuropathol Exp Neurol 64:722-729

10. Wosik K, Cayrol R, Dodelet-Devillers A, Berthelet F, Bernard M, Moumdjian R, Bouthillier A, Reudelhuber TL, Prat A (2007) Angiotensin II controls occludin function and is required for blood brain barrier maintenance: relevance to multiple sclerosis. J Neurosci 27:9032-9042

11. Gay D, Esiri M (1991) Blood-brain barrier damage in acute multiple sclerosis plaques. An immunocytological study. Brain 114:557-572

12. Su JJ, Osoegawa M, Matsuoka T, Minohara M, Tanaka M, Ishizu T, Mihara F, Taniwaki T, Kira J (2006) Upregulation of vascular growth factors in multiple sclerosis: correlation with MRI findings. J Neurol Sci 243:21-30

13. Dousset V, Brochet B, Deloire MS, Lagoarde L, Barroso B, Caille JM, Petry KG (2006) MR imaging of relapsing multiple sclerosis patients using ultra-small-particle iron oxide and compared with gadolinium. Am J Neuroradiol 27:1000-1005

14. Vellinga MM, Engberink RD, Seewann A, Pouwels $P$, Wattjes $M$, van der Pol S, Pering C, Polman CH, de Vries HE, Geurts JJ, Barkhof F (2008) Pluriformity of inflammation in multiple sclerosis shown by ultra-small iron oxide particle enhancement. Brain 131:800-807

15. Ladewig G, Jestaedt L, Misselwitz B, Solymosi L, Toyka K, Bendszus M, Stoll G (2009) Spatial diversity of blood-brain barrier alteration and macrophage invasion in experimental autoimmune encephalomyelitis: a comparative MRI study. Exp Neurol 220:207-211. doi:10.1016/j. expneurol.2009.08.027

16. Mayhan WG (1999) VEGF increases permeability of the blood-brain barrier via a nitric oxide synthase/cGMP-dependent pathway. Am J Physiol 276:C1148-1153

17. Barleon B, Sozzani S, Zhou D, Weich HA, Mantovani A, Marmé D (1996) Migration of human monocytes in response to vascular endothelial growth factor (VEGF) is mediated via the VEGF receptor flt-1. Blood 87:3336-3343

18. Clauss M, Gerlach M, Gerlach H, Brett J, Wang F, Familletti PC, Pan YC, Olander JV, Connolly DT, Stern D (1990) Vascular permeability factor: a tumor-derived polypeptide that induces endothelial cell and monocyte procoagulant activity, and promotes monocyte migration. J Exp Med 172:1535-1545

19. Proescholdt MA, Heiss JD, Walbridge S, Mühlhauser J, Capogrossi MC, Oldfield EH, Merrill MJ (1999) Vascular endothelial growth factor (VEGF) modulates vascular permeability and inflammation in rat brain. J Neuropathol Exp Neurol 58:613-627

20. Virgintino D, Girolamo F, Errede M, Capobianco C, Robertson D, Stallcup WB, Perris R, Roncali L (2007) An intimate interplay between precocious, migrating pericytes and endothelial cells governs human fetal brain angiogenesis. Angiogenesis 10:35-45

21. Sung HK, Michael IP, Nagy A (2010) Multifaceted role of vascular endothelial growth factor signaling in adult tissue physiology: an emerging concept with clinical implications. Curr Opin Hematol 17:206-212

22. Holley JE, Newcombe J, Whatmore JL, Gutowski NJ (2010) Increased blood vessel density and endothelial cell proliferation in multiple sclerosis cerebral white matter. Neurosci Lett 470:65-70

23. Ludwin S (2001) Vascular proliferation and angiogenesis in MS: clinical and pathogenic implications. J Neuropath Exp Neurol 60:505

24. Vagnucci AH Jr, Li WW (2003) Alzheimer's disease and angiogenesis. Lancet 361:605-608 
25. Desai Bradaric B, Patel A, Schneider JA, Carvey PM, Hendey B (2012) Evidence for angiogenesis in Parkinson's disease, incidental Lewy body disease, and progressive supranuclear palsy. J Neural Transm 119:59-71

26. Plate KH, Scholz A, Dumont DJ (2012) Tumor angiogenesis and anti-angiogenic therapy in malignant gliomas revisited. Acta Neuropathol 124:763-775

27. Xiong M, Elson G, Legarda D, Leibovich SJ (1998) Production of vascular endothelial growth factor by murine macrophages - regulation by hypoxia, lactate, and the inducible nitric oxide synthase pathway. Am J Pathol 153:587-598

28. Papadaki EZ, Simos PG, Mastorodemos VC, Panou T, Maris TG, Karantanas AH, Plaitakis A (2014) Regional MRI perfusion measures predict motor/ executive function in patients with Clinically Isolated Syndrome. Behav Neurol http://dx.doi.org/10.1155/2014/252419

29. Fog $T$ (1965) The topography of plaques in multiple sclerosis. With special reference to cerebral plaques. Acta Neurol Scand 41(Suppl 15):1-161

30. Macchi G (1954) The pathology of the blood vessels in multiple sclerosis. J Neuropath Exp Neurol 13:378-84

31. Putnam TJ (1933) The pathogenesis of multiple sclerosis: a possible vascular factor. N Engl J Med 209:786-790

32. Rindfleisch E (1863) Histologische Details zu der grauen degeneration von Gehirn und Rückenmark. Virchow's Archiv für Pathologische Anatomie und Physiologie und für klinische Medizin 26:474-83

33. Scheinker M (1943) Histogenesis of the early lesions of multiple sclerosis. 1. Significance of the vascular changes. Arch Neurol Psychiat 49:178

34. Broman T (1947) Supravital analysis of disorders in the cerebral vascular permeability II. Two cases of multiple sclerosis. Acta Psychiatr Neurol Scand (Suppl) 46:58-71

35. Proescholdt MA, Jacobson S, Tresser N, Oldfield EH, Merrill MJ (2002) Vascular endothelial growth factor is expressed in multiple sclerosis plaques and can induce inflammatory lesions in experimental allergic encephalomyelitis rats. J Neuropathol Exp Neurol 61:914-925

36. Karlik SJ, Roscoe WA, Patinote C, Contino-Pepin C (2012) Targeting vascular changes in lesions in multiple sclerosis and experimental autoimmune encephalomyelitis. Cent Nerv Syst Agents Med Chem 12:7-14

37. Kirk S, Frank JA, Karlik S (2004) Angiogenesis in multiple sclerosis: is it good, bad or an epiphenomenon? J Neurol Sci 217:125-130

38. Trapp BD, Stys PK (2009) Virtual hypoxia and chronic necrosis of demyelinated axons in multiple sclerosis. Lancet Neurol 8:280-291

39. Argaw AT, Asp L, Zhang J, Navrazhina K, Pham T, Mariani JN, Mahase S, Dutta DJ, Seto J, Kramer EG, Ferrara N, Sofroniew MV, John GR (2012) Astrocyte-derived VEGF-A drives blood-brain barrier disruption in CNS inflammatory disease. J Clin Invest 122:2454-2468

40. Boroujerdi A, Welser-Alves JV, Milner R (2013) Extensive vascular remodeling in the spinal cord of pre-symptomatic experimental autoimmune encephalomyelitis mice; increased vessel expression of fibronectin and the a5 $\beta 1$ integrin. Exp Neurol 250:43-51

41. Daniel PM, Lam DK, Pratt OE (1981) Changes in the effectiveness of the blood-brain and blood-spinal cord barriers in experimental allergic encephalomyelitis. J Neurol Sci 52:211-219

42. Errede M, Girolamo F, Ferrara G, Strippoli M, Morando S, Boldrin V, Rizzi M, Uccelli A, Perris R, Bendotti C, Salmona M, Roncali L, Virgintino D (2012) Blood-brain barrier alterations in the cerebral cortex in experimental autoimmune encephalomyelitis. J Neuropathol Exp Neurol 71:840-854

43. Juhler M, Barry DI, Offner H, Konat G, Klinken L, Paulson OB (1984) Blood-brain and blood-spinal cord barrier permeability during the course of experimental allergic encephalomyelitis in the rat. Brain Res 302:347-355

44. Zlokovic BV, Skundric DS, Segal MB, Colover J, Jankov RM, Pejnovic N, Lackovic V, Mackic J, Lipovac MN, Dawson H, Kasp E, Dumonde D, Rakic L (1989) Blood-brain barrier permeability changes during acute allergic encephalomyelitis induced in the guinea pig. Metab Brain Dis 4:33-40

45. MacMillan CJ, Starkey RJ, Easton AS (2011) Angiogenesis is regulated by angiopoietins during experimental autoimmune encephalomyelitis and is indirectly related to vascular permeability. J Neuropathol Exp Neurol 70:1107-23

46. Roscoe WA, Welsh ME, Carter DE, Karlik SJ (2009) VEGF and angiogenesis in acute and chronic MOG((35-55)) peptide induced EAE. J Neuroimmunol 209:6-15

47. Kirk SL, Karlik SJ (2003) VEGF and vascular changes in chronic neuroinflammation. J Autoimmun 21:353-363

48. Piraino PS, Yednock TA, Messersmith EK, Pleiss MA, Freedman SB, Hammond RR, Karlik SJ (2005) Spontaneous remyelination following prolonged inhibition of alpha4 integrin in chronic EAE. J Neuroimmunol 167:53-63
49. Sobel RA, Blanchette BW, Bhan AK, Colvin RB (1984) The immunopathology of experimental allergic encephalomyelitis. II. Endothelial cell la increases prior to inflammatory cell infiltration. J Immunol 132:2402-2407

50. Seabrook TJ, Littlewood-Evans A, Brinkmann V, Pöllinger B, Schnell C, Hiestand PC (2010) Angiogenesis is present in experimental autoimmune encephalomyelitis and pro-angiogenic factors are increased in multiple sclerosis lesions. J Neuroinflammation 7:95. doi:10.1186/1742-2094-7-95

51. Mor F, Quintana FJ, Cohen IR (2004) Angiogenesis-inflammation cross-talk: vascular endothelial growth factor is secreted by activated T cells and induces Th1 polarization. J Immunol 172:4618-4623

52. Sasaki M, Lankford KL, Brown RJ, Ruddle NH, Kocsis JD (2010) Focal experimental autoimmune encephalomyelitis in the Lewis rat induced by immunization with myelin oligodendrocyte glycoprotein and intraspinal injection of vascular endothelial growth factor. Glia 58:1523-1531

53. Tham E, Gielen AW, Khademi M, Martin C, Piehl F (2006) Decreased expression of VEGF-A in rat experimental autoimmune encephalomyelitis and in cerebrospinal fluid mononuclear cells from patients with multiple sclerosis. Scand J Immunol 64:609-622

54. McCloskey DP, Tana MH, Scharfman HE (2008) Modulation of vascular endothelial growth factor (VEGF) expression in motor neurons and its electrophysiological effects. Brain Res Bull 76:36-44

55. Knizetova P, Ehrmann J, Hlobilkova A, Vancova I, Kalita O, Kolar Z, Bartek J (2008) Autocrine regulation of glioblastoma cell cycle progression, viability and radioresistance through the VEGF-VEGFR2 (KDR) interplay. Cell Cycle 7:2553-2561

56. Storkebaum E, Lambrechts D, Carmeliet P (2004) VEGF: once regarded as a specific angiogenic factor, now implicated in neuroprotection. Bioessays 26:943-954

57. Zhang ZG, Zhang L, Tsang W, Soltanian-Zadeh H, Morris D, Zhang R, Goussev A, Powers C, Yeich T, Chopp M (2002) Correlation of VEGF and angiopoietin expression with disruption of blood-brain barrier and angiogenesis after focal cerebral ischemia. J Cereb Blood Flow Metab 22:379-392

58. Graumann U, Reynolds R, Steck AJ, Schaeren-Wiemers N (2003) Molecular changes in normal appearing white matter in multiple sclerosis are characteristic of neuroprotective mechanisms against hypoxic insult. Brain Pathol 13:554-573

59. Theoharides TC, Konstantinidou AD (2007) Corticotropin-releasing hormone and the blood-brain-barrier. Front Biosci 12:1615-1628

60. van Bruggen N, Thibodeaux H, Palmer JT, Lee WP, Fu L, Cairns B, Tumas D, Gerlai R, Williams SP, van Lookeren CM, Ferrara N (1999) VEGF antagonism reduces edema formation and tissue damage after ischemia/reperfusion injury in the mouse brain. J Clin Invest 104:1613-1620

61. Benton RL, Whittemore SR (2003) VEGF165 therapy exacerbates secondary damage following spinal cord injury. Neurochem Res 28:1693-1703

62. Widenfalk J, Lipson A, Jubran M, Hofstetter C, Ebendal T, Cao Y, Olson L (2003) Vascular endothelial growth factor improves functional outcome and decreases secondary degeneration in experimental spinal cord contusion injury. Neuroscience 120:951-960

63. lacobaeus E, Amoudruz P, Ström M, Khademi M, Brundin L, Hillert J, Kockum I, Malmström V, Olsson T, Tham E, Piehl F (2011) The expression of VEGF-A is down regulated in peripheral blood mononuclear cells of patients with secondary progressive multiple sclerosis. PLoS One 6:e19138

64. MacMillan CJ, Furlong SJ, Doucette CD, Chen PL, Hoskin DW, Easton AS (2012) Bevacizumab diminishes experimental autoimmune encephalomyelitis by inhibiting spinal cord angiogenesis and reducing peripheral T-cell responses. J Neuropathol Exp Neurol 71:983-999

65. Lambrechts D, Storkebaum E, Morimoto M, Del-Favero J, Desmet F, Marklund SL, Wyns S, Thijs V, Andersson J, van Marion I, Al-Chalabi A, Bornes S, Musson R, Hansen V, Beckman L, Adolfsson R, Pall HS, Prats $H$, Vermeire S, Rutgeerts $P$, Katayama S, Awata T, Leigh N, Lang-Lazdunski L, Dewerchin M, Shaw C, Moons L, Vlietinck R, Morrison KE, Robberecht W, Van Broeckhoven C et al (2003) VEGF is a modifier of amyotrophic lateral sclerosis in mice and humans and protects motoneurons against ischemic death. Nat Genet 34:383-394

66. Oosthuyse B, Moons L, Storkebaum E, Beck H, Nuyens D, Brusselmans K, Van Dorpe J, Hellings P, Gorselink M, Heymans S, Theilmeier G, Dewerchin M, Laudenbach V, Vermylen P, Raat $H$, Acker T, Vleminckx V, Van Den Bosch L, Cashman N, Fujisawa H, Drost MR, Sciot R, Bruyninckx F, Hicklin DJ, Ince C, Gressens P, Lupu F, Plate KH, Robberecht W, Herbert JM et al (2001) Deletion of the hypoxia response element in the vascular endothelial growth factor promoter causes motor neuron degeneration. Nat Genet 28:131-138 
67. Storkebaum E, Lambrechts D, Dewerchin M, Moreno-Murciano MP, Appelmans S, Oh H, Van Damme P, Rutten B, Man WY, De Mol M, Wyns S, Manka D, Vermeulen K, Van Den Bosch L, Mertens N, Schmitz C, Robberecht W, Conway EM, Collen D, Moons L, Carmeliet P (2005) Treatment of motoneuron degeneration by intracerebroventricular delivery of VEGF in a rat model of ALS. Nat Neurosci 8:85-92

68. Sondell M, Lundborg G, Kanje M (1999) Vascular endothelial growth factor has neurotrophic activity and stimulates axonal outgrowth, enhancing cell survival and Schwann cell proliferation in the peripheral nervous system. J Neurosci 19:5731-5740

69. Argaw AT, Gurfein BT, Zhang Y, Zameer A, John GR (2009) VEGF-mediated disruption of endothelial CLN-5 promotes blood-brain barrier breakdown. Proc Natl Acad Sci U S A 106:1977-1982

70. Rosenstein JM, Krum JM (2004) New roles for VEGF in nervous tissue-beyond blood vessels. Exp Neurol 187:246-253

71. Okada S, Nakamura M, Katoh H, Miyao T, Shimazaki T, Ishii K, Yamane J, Yoshimura A, Iwamoto Y, Toyama Y, Okano H (2006) Conditional ablation of Stat3 or Socs3 discloses a dual role for reactive astrocytes after spinal cord injury. Nat Med 12:829-834

72. Choi JS, Kim HY, Cha JH, Choi JY, Park SI, Jeong CH, Jeun SS, Lee MY (2007) Upregulation of vascular endothelial growth factor receptors Flt-1 and Flk-1 following acute spinal cord contusion in rats. J Histochem Cytochem 55:821-830

73. Herz J, Reitmeir R, Hagen SI, Reinboth BS, Guo Z, Zechariah A, ElAli A, Doeppner TR, Bacigaluppi M, Pluchino S, Kilic U, Kilic E, Hermann DM (2012) Intracerebroventricularly delivered VEGF promotes contralesional corticorubral plasticity after focal cerebral ischemia via mechanisms involving anti-inflammatory actions. Neurobiol Dis 45:1077-1085

74. Heil M, Clauss M, Suzuki K, Buschmann IR, Willuweit A, Fischer S, Schaper W (2000) Vascular endothelial growth factor (VEGF) stimulates monocyte migration through endothelial monolayers via increased integrin expression. Eur J Cell Biol 79:850-857

75. Ishizu T, Osoegawa M, Mei FJ, Kikuchi H, Tanaka M, Takakura Y, Minohara M, Murai H, Mihara F, Taniwaki T, Kira J (2005) Intrathecal activation of the IL-17/IL-8 axis in opticospinal multiple sclerosis. Brain 128:988-1002

76. Cho ML, Jung YO, Moon YM, Min SY, Yoon CH, Lee SH, Park SH, Cho CS, Jue DM, Kim HY (2006) Interleukin-18 induces the production of vascular endothelial growth factor (VEGF) in rheumatoid arthritis synovial fibroblasts via AP-1-dependent pathways. Immunol Lett 103:159-166

77. Suarez S, Ballmer-Hofer K (2001) VEGF transiently disrupts gap junctional communication in endothelial cells. J Cell Sci 114:1229-1235

78. Beazley-Long N, Hua J, Jehle T, Hulse RP, Dersch R, Lehrling C, Bevan H, Qiu Y, Lagrèze WA, Wynick D, Churchill AJ, Kehoe P, Harper SJ, Bates DO, Donaldson LF (2013) VEGF-A165b is an endogenous neuroprotective splice isoform of vascular endothelial growth factor $A$ in vivo and in vitro. Am J Pathol 183:918-929. doi:10.1016/j.ajpath.2013.05.031

79. Kawamura H, Li X, Harper SJ, Bates DO, Claesson-Welsh L (2008) Vascular endothelial growth factor (VEGF)-A165b is a weak in vitro agonist for VEGF receptor-2 due to lack of coreceptor binding and deficient regulation of kinase activity. Cancer Res 68:4683-4692. doi:10.1158/0008-5472.CAN-07-6577

80. Liu Y, Cox SR, Morita T, Kourembanas S (1995) Hypoxia regulates vascular endothelial growth factor gene expression in endothelial cells. Identification of a $5^{\prime}$ enhancer. Circ Res 77:638-643

81. Lassmann $\mathrm{H}$ (2003) Hypoxia-like tissue injury as a component of multiple sclerosis lesions. J Neurol Sci 206:187-91

82. Distler JH, Hirth A, Kurowska-Stolarska M, Gay RE, Gay S, Distler O (2003) Angiogenic and angiostatic factors in the molecular control of angiogenesis. Q J Nucl Med 47:149-161

83. Frost EE, Nielsen JA, Le TQ, Armstrong RC (2003) PDGF and FGF2 regulate oligodendrocyte progenitor responses to demyelination. J Neurobiol 54:457-472

84. Van Meir EG (1995) Cytokines and tumors of the central nervous system. Glia 15:264-288

85. Haufschild T, Shaw SG, Kesselring J, Flammer J (2001) Increased endothelin-1 plasma levels in patients with multiple sclerosis. J Neuroophthalmol 21:37-38

86. Shin T, Kang B, Tanuma N, Matsumoto Y, Wie M, Ahn M, Kang J (2001) Intrathecal administration of endothelin-1 receptor antagonist ameliorates autoimmune encephalomyelitis in Lewis rats. Neuroreport 12:1465-1468

87. Li L, Welser-Alves J, van der Flier A, Boroujerdi A, Hynes RO, Milner R (2012) An angiogenic role for the a5 31 integrin in promoting endothelial cell proliferation during cerebral hypoxia. Exp Neurol 237:46-54

88. Cunnea P, McMahon J, O'Connell E, Mashayekhi K, Fitzgerald U, McQuaid S (2010) Gene expression analysis of the microvascular compartment in multiple sclerosis using laser microdissected blood vessels. Acta Neuropathol 119:601-15. doi:10.1007/s00401-009-0618-9

89. Jackson JR, Seed MP, Kircher CH, Willoughby DA, Winkler JD (1997) The codependence of angiogenesis and chronic inflammation. FASEB J 11:457-465

90. Ward NL, Lamanna JC (2004) The neurovascular unit and its growth factors: coordinated response in the vascular and nervous systems. Neurol Res 26:870-883

91. Carmeliet P, Ruiz de Almodovar C (2013) VEGF ligands and receptors: implications in neurodevelopment and neurodegeneration. Cell Mol Life Sci 70:1763-1778

92. Carmeliet $\mathrm{P}$, Tessier-Lavigne M (2005) Common mechanisms of nerve and blood vessel wiring. Nature 436:193-200

93. Leventhal C, Rafii S, Rafii D, Shahar A, Goldman SA (1999) Endothelial trophic support of neuronal production and recruitment from the adult mammalian subependyma. Mol Cell Neurosci 13:450-464

94. Shen Q, Goderie SK, Jin L, Karanth N, Sun Y, Abramova N, Vincent P, Pumiglia K, Temple S (2004) Endothelial cells stimulate self-renewal and expand neurogenesis of neural stem cells. Science 304:1338-1340

95. Zacchigna S, Lambrechts D, Carmeliet P (2008) Neurovascular signalling defects in neurodegeneration. Nat Rev Neurosci 9:169-181

96. Jin K, Zhu Y, Sun Y, Mao XO, Xie L, Greenberg DA (2002) Vascular endothelial growth factor (VEGF) stimulates neurogenesis in vitro and in vivo. Proc Natl Acad Sci U S A 99:11946-11950

97. Zhao C, Deng W, Gage FH (2008) Mechanisms and functional implications of adult neurogenesis. Cell 132:645-660

98. Ma YY, Li KY, Wang JJ, Huang YL, Huang Y, Sun FY (2009) Vascular endothelial growth factor acutely reduces calcium influx via inhibition of the Ca2+ channels in rat hippocampal neurons. J Neurosci Res 87:393-402. doi:10.1002/jnr.21859

99. Hayakawa K, Pham LD, Som AT, Lee BJ, Guo S, Lo EH, Arai K (2011) Vascular endothelial growth factor regulates the migration of oligodendrocyte precursor cells. J Neurosci 31:10666-10670. doi:10.1523/JNEUROSCl.1944-11.2011

100. Gao P, Shen F, Gabriel RA, Law D, Yang E, Yang GY, Young WL, Su H (2009) Attenuation of brain response to vascular endothelial growth factor-mediated angiogenesis and neurogenesis in aged mice. Stroke 40:3596-3600

101. Kazanis I, Lathia JD, Vadakkan TJ, Raborn E, Wan R, Mughal MR, Eckley DM, Sasaki T, Patton B, Mattson MP, Hirschi KK, Dickinson ME, Ffrench-Constant C (2010) Quiescence and activation of stem and precursor cell populations in the subependymal zone of the mammalian brain are associated with distinct cellular and extracellular matrix signals. J Neurosci 30:9771-9781

102. Kokovay E, Goderie S, Wang Y, Lotz S, Lin G, Sun Y, Roysam B, Shen Q, Temple S (2010) Adult SVZ lineage cells home to and leave the vascular niche via differential responses to SDF1/CXCR4 signaling. Cell Stem Cell 7:163-173

103. Patel JR, McCandless EE, Dorsey D, Klein RS (2010) CXCR4 promotes differentiation of oligodendrocyte progenitors and remyelination. Proc Natl Acad Sci U S A 107:11062-11067. doi:10.1073/pnas.1006301107

104. Kerever A, Schnack J, Vellinga D, Ichikawa N, Moon C, Arikawa-Hirasawa E, Efird JT, Mercier F (2007) Novel extracellular matrix structures in the neural stem cell niche capture the neurogenic factor fibroblast growth factor 2 from the extracellular milieu. Stem Cells 25:2146-2157

105. Clemente D, Ortega MC, Arenzana FJ, de Castro F (2011) FGF-2 and Anosmin-1 are selectively expressed in different types of multiple sclerosis lesions. J Neurosci 31:14899-14909. doi:10.1523/JNEUROSCI.1158-11.2011

106. Sohn J, Selvaraj V, Wakayama K, Orosco L, Lee E, Crawford SE, Guo F, Lang J, Horiuchi M, Zarbalis K, Itoh T, Deng W, Pleasure D (2012) PEDF is a novel oligodendrogenic morphogen acting on the adult SVZ and corpus callosum. J Neurosci 32:12152-12164. doi:10.1523/JNEUROSCI.0628-12.2012

107. Aguirre A, Rubio ME, Gallo V (2010) Notch and EGFR pathway interaction regulates neural stem cell number and self-renewal. Nature 467:323-327

108. Rash BG, Lim HD, Breunig JJ, Vaccarino FM (2011) FGF signaling expands embryonic cortical surface area by regulating Notch-dependent neurogenesis. J Neurosci 31:15604-15617. doi:10.1523/JNEUROSCl.4439-11.2011

109. Cha YK, Kim YH, Ahn YH, Koh JY (2000) Epidermal growth factor induces oxidative neuronal injury in cortical culture. J Neurochem 75:298-303

110. Levy YA, Fainberg KM, Amidror T, Regev K, Auriel E, Karni A (2013) High and dysregulated secretion of epidermal growth factor from immune cells of patients with relapsing-remitting multiple sclerosis. J Neuroimmunol 257:82-89. doi:10.1016/j.jneuroim.2013.01.012

111. Calza L, Giuliani A, Fernandez M, Pirondi S, D'Intino G, Aloe L, Giardino L (2003) Neural stem cells and cholinergic neurons: regulation by immunolesion and treatment with mitogens, retinoic acid, and nerve growth factor. Proc Natl Acad Sci U S A 100:7325-7330 
112. Kim H, Li Q, Hempstead BL, Madri JA (2004) Paracrine and autocrine functions of brain-derived neurotrophic factor (BDNF) and nerve growth factor (NGF) in brain-derived endothelial cells. J Biol Chem 279:33538-33546

113. Mashayekhi F, Salehi Z, Jamalzadeh HR (2012) Quantitative analysis of cerebrospinal fluid brain derived neurotrophic factor in the patients with multiple sclerosis. Acta Med (Hradec Kralove) 55:83-86

114. Laudiero LB, Aloe L, Levi-Montalcini R, Buttinelli C, Schilter D, Gillessen S, Otten U (1992) Multiple sclerosis patients express increased levels of beta-nerve growth factor in cerebrospinal fluid. Neurosci Lett 147:9-12

115. Stadelmann C, Kerschensteiner M, Misgeld T, Brück W, Hohlfeld R, Lassmann H (2002) BDNF and gp145trkB in multiple sclerosis brain lesions: neuroprotective interactions between immune and neuronal cells? Brain 125:75-85

116. Kalinowska-Lyszczarz A, Losy J (2012) The role of neurotrophins in multiple sclerosis-pathological and clinical implications. Int J Mol Sci 13:13713-13725. doi:10.3390/ijms131013713

117. Larrivée B, Freitas C, Suchting S, Brunet I, Eichmann A (2009) Guidance of vascular development: lessons from the nervous system. Circ Res 104:428-441. doi:10.1161/CIRCRESAHA.108.188144

118. Mizutani K, Yoon K, Dang L, Tokunaga A, Gaiano N (2007) Differential Notch signalling distinguishes neural stem cells from intermediate progenitors. Nature 449:351-355

119. Kume T (2009) Novel insights into the differential functions of Notch ligands in vascular formation. J Angiogenes Res 1:8

120. Shimojo H, Ohtsuka T, Kageyama R (2008) Oscillations in notch signaling regulate maintenance of neural progenitors. Neuron 58:52-64

121. Tavazoie M, Van der Veken L, Silva-Vargas V, Louissaint M, Colonna L, Zaidi B, Garcia-Verdugo JM, Doetsch F (2008) A specialized vascular niche for adult neural stem cells. Cell Stem Cell 3:279-288

122. Juryńczyk M, Selmaj K (2010) Notch: a new player in MS mechanisms. J Neuroimmunol 218:3-11. doi:10.1016/j.jneuroim.2009.08.010

123. Hashimoto M, Ishii K, Nakamura Y, Watabe K, Kohsaka S, Akazawa C (2008) Neuroprotective effect of sonic hedgehog up-regulated in Schwann cells following sciatic nerve injury. J Neurochem 107:918-927

124. Hirsch C, Campano LM, Wohrle S, Hecht A (2007) Canonical Wnt signaling transiently stimulates proliferation and enhances neurogenesis in neonatal neural progenitor cultures. Exp Cell Res 313:572-587

125. Xie C, Li Z, Zhang GX, Guan Y (2013) Wnt signaling in Remyelination in multiple sclerosis: friend or foe? Mol Neurobiol. doi:10.1007/s12035-013-8584-6

126. Alvarez II, Dodelet-Devillers A, Kebir H, Ifergan I, Fabre PJ, Terouz S, Sabbagh M, Wosik K, Bourbonnière L, Bernard M, van Horssen J, de Vries HE, Charron F, Prat A (2011) The Hedgehog pathway promotes blood-brain barrier integrity and CNS immune quiescence. Science 334:1727-1731. doi:10.1126/science.1206936

127. Wälchli T, Pernet V, Weinmann O, Shiu JY, Guzik-Kornacka A, Decrey G, Yüksel D, Schneider H, Vogel J, Ingber DE, Vogel V, Frei K, Schwab ME (2013) Nogo-A is a negative regulator of CNS angiogenesis. Proc Natl Acad Sci U S A 110:E1943-1952. doi:10.1073/pnas.1216203110

128. Karnezis T, Mandemakers W, McQualter JL, Zheng B, Ho PP, Jordan KA, Murray BM, Barres B, Tessier-Lavigne M, Bernard CC (2004) The neurite outgrowth inhibitor Nogo A is involved in autoimmune-mediated demyelination. Nat Neurosci 7:736-744

129. Bin JM, Rajasekharan S, Kuhlmann T, Hanes I, Marcal N, Han D, Rodrigues SP, Leong SY, Newcombe J, Antel JP, Kennedy TE (2013) Full-length and fragmented netrin-1 in multiple sclerosis plaques are inhibitors of oligodendrocyte precursor cell migration. Am J Pathol 183:673-680

130. Sobel RA (2005) Ephrin A receptors and ligands in lesions and normalappearing white matter in multiple sclerosis. Brain Pathol 15:35-45

131. Munro KM, Dixon KJ, Gresle MM, Jonas A, Kemper D, Doherty W, Fabri L, Owczarek CM, Pearse M, Boyd AW, Kilpatrick TJ, Butzkueven H, Turnley AM (2013) EphA4 receptor tyrosine kinase is a modulator of onset and disease severity of experimental autoimmune encephalomyelitis (EAE). PLoS One 8 : e55948. doi:10.1371/journal.pone.0055948

132. Syed YA, Hand E, Möbius W, Zhao C, Hofer M, Nave KA, Kotter MR (2011) Inhibition of CNS remyelination by the presence of semaphorin 3A. J Neurosci 31:3719-3728

133. Williams A, Piaton G, Aigrot MS, Belhadi A, Théaudin M, Petermann F, Thomas JL, Zalc B, Lubetzki C (2007) Semaphorin 3A and 3 F: key players in myelin repair in multiple sclerosis? Brain 130:2554-2565

134. Okuno T, Nakatsuji Y, Kumanogoh A (2011) The role of immune semaphorins in multiple sclerosis. FEBS Lett 585:3829-3835
135. Solomon BD, Mueller C, Chae WJ, Alabanza LM, Bynoe MS (2011) Neuropilin-1 attenuates autoreactivity in experimental autoimmune encephalomyelitis. Proc Natl Acad Sci U S A 108:2040-2045

136. Liu XS, Chopp M, Zhang RL, Hozeska-Solgot A, Gregg SC, Buller B, Lu M, Zhang ZG (2009) Angiopoietin 2 mediates the differentiation and migration of neural progenitor cells in the subventricular zone after stroke. J Biol Chem 284:22680-22689

137. Wang $L$, Zhang Z, Wang $Y$, Zhang R, Chopp M (2004) Treatment of stroke with erythropoietin enhances neurogenesis and angiogenesis and improves neurological function in rats. Stroke 35:1732-1737

138. Spence RD, Voskuhl RR (2012) Neuroprotective effects of estrogens and androgens in CNS inflammation and neurodegeneration. Front Neuroendocrinol 33:105-115. doi:10.1016/j.yfrne.2011.12.001

139. Suzuki S, Gerhold LM, Böttner M, Rau SW, Dela Cruz C, Yang E, Zhu H, Yu J, Cashion AB, Kindy MS, Merchenthaler I, Gage FH, Wise PM (2007) Estradiol enhances neurogenesis following ischemic stroke through estrogen receptors alpha and beta. J Comp Neurol 500:1064-1075

140. Crawford DK, Mangiardi M, Song B, Patel R, Du S, Sofroniew MV, Voskuhl RR, Tiwari-Woodruff SK (2010) Oestrogen receptor beta ligand: a novel treatment to enhance endogenous functional remyelination. Brain 133:2999-3016

141. Zhang R, Wang L, Zhang L, Chen J, Zhu Z, Zhang Z, Chopp M (2003) Nitric oxide enhances angiogenesis via the synthesis of vascular endothelial growth factor and cGMP after stroke in the rat. Circ Res 92:308-313

142. Zhang R, Zhang L, Zhang Z, Wang Y, Lu M, Lapointe M, Chopp M (2001) A nitric oxide donor induces neurogenesis and reduces functional deficits after stroke in rats. Ann Neurol 50:602-611

143. Li Q, Ford MC, Lavik EB, Madri JA (2006) Modeling the neurovascular niche: VEGF- and BDNF-mediated cross-talk between neural stem cells and endothelial cells: an in vitro study. J Neurosci Res 84:1656-1668

144. Fong GH (2008) Mechanisms of adaptive angiogenesis to tissue hypoxia. Angiogenesis 11:121-140

145. Mohyeldin A, Garzon-Muvdi T, Quinones-Hinojosa A (2010) Oxygen in stem cell biology: a critical component of the stem cell niche. Cell Stem Cell 7:150-161

146. Imitola J, Raddassi K, Park Kl, Mueller FJ, Nieto M, Teng YD, Frenkel D, Li J, Sidman RL, Walsh CA, Snyder EY, Khoury SJ (2004) Directed migration of neural stem cells to sites of CNS injury by the stromal cell-derived factor 1alpha/CXC chemokine receptor 4 pathway. Proc Natl Acad Sci U S A 101:18117-18122

147. Arai K, Lo EH (2009) An oligovascular niche: cerebral endothelial cells promote the survival and proliferation of oligodendrocyte precursor cells. J Neurosci 29:4351-4355

148. Chang A, Nishiyama A, Peterson J, Prineas J, Trapp BD (2000) NG2-positive oligodendrocyte progenitor cells in adult human brain and multiple sclerosis lesions. J Neurosci 20:6404-6412

149. Chang A, Tourtellotte WW, Rudick R, Trapp BD (2002) Premyelinating oligodendrocytes in chronic lesions of multiple sclerosis. N Engl J Med 346:165-173

150. Gadea A, Aguirre A, Haydar TF, Gallo V (2009) Endothelin-1 regulates oligodendrocyte development. J Neurosci 29:10047-10062

151. Greenberg DA, Jin K (2005) From angiogenesis to neuropathology. Nature 438:954-959

152. Sanai N, Tramontin AD, Quinones-Hinojosa A, Barbaro NM, Gupta N, Kunwar S, Lawton MT, McDermott MW, Parsa AT, Manuel-Garcia Verdugo J, Berger MS, Alvarez-Buylla A (2004) Unique astrocyte ribbon in adult human brain contains neural stem cells but lacks chain migration. Nature 427:740-744

153. Pluchino S, Muzio L, Imitola J, Deleidi M, Alfaro-Cervello C, Salani G, Porcheri C, Brambilla E, Cavasinni F, Bergamaschi A, Garcia-Verdugo JM, Comi G, Khoury SJ, Martino G (2008) Persistent inflammation alters the function of the endogenous brain stem cell compartment. Brain 131:2564-2578

154. Rasmussen S, Imitola J, Ayuso-Sacido A, Wang Y, Starossom SC, Kivisäkk P, Zhu B, Meyer M, Bronson RT, Garcia-Verdugo JM, Khoury SJ (2011) Reversible neural stem cell niche dysfunction in a model of multiple sclerosis. Ann Neurol 69:878-891. doi:10.1002/ana.22299

155. Lehtinen MK, Zappaterra MW, Chen X, Yang YJ, Hill AD, Lun M, Maynard T, Gonzalez D, Kim S, Ye P, D'Ercole AJ, Wong ET, LaMantia AS, Walsh CA (2011) The cerebrospinal fluid provides a proliferative niche for neural progenitor cells. Neuron 69:893-905. doi:10.1016/j.neuron.2011.01.023

156. Sun X, Tanaka M, Kondo S, Okamoto K, Hirai S (1998) Clinical significance of reduced cerebral metabolism in multiple sclerosis: a combined PET and MRI study. Ann Nucl Med 12:89-94 
157. Swank RL, Roth JG, Woody DC Jr (1983) Cerebral blood flow and red cell delivery in normal subjects and in multiple sclerosis. Neurol Res 5:37-59

158. Law M, Saindane AM, Ge Y, Babb JS, Johnson G, Mannon L, Herbert J, Grossman RI (2004) Microvascular abnormality in relapsing-remitting multiple sclerosis: perfusion MR imaging findings in normal-appearing white matter. Radiology 231:645-652

159. Varga AW, Johnson G, Babb JS, Herbert J, Grossman Rl, Inglese M (2009) White matter hemodynamic abnormalities precede sub-cortical gray matter changes in multiple sclerosis. J Neurol Sci 282:28-33

160. Adhya S, Johnson G, Herbert J, Jaggi H, Babb JS, Grossman RI, Inglese M (2006) Pattern of hemodynamic impairment in multiple sclerosis: dynamic susceptibility contrast perfusion MR imaging at 3.0 T. Neuroimage 33:1029-1035

161. Rashid W, Parkes LM, Ingle GT, Chard DT, Toosy AT, Altmann DR, Symms MR, Tofts PS, Thompson AJ, Miller DH (2004) Abnormalities of cerebral perfusion in multiple sclerosis. J Neurol Neurosurg Psychiatry 75:1288-1293

162. Juurlink BH (1998) The multiple sclerosis lesion: initiated by a localized hypoperfusion in a central nervous system where mechanisms allowing leukocyte infiltration are readily upregulated? Med Hypotheses 51:299-303

163. Haselhorst R, Kappos L, Bilecen D, Scheffler K, Möri D, Radü EW, Seelig J (2000) Dynamic susceptibility contrast MR imaging of plaque development in multiple sclerosis: application of an extended blood-brain barrier leakage correction. J Magn Reson Imaging 11:495-505

164. Wuerfel J, Bellmann-Strobl J, Brunecker P, Aktas O, McFarland H, Villringer A, Zipp F (2004) Changes in cerebral perfusion precede plaque formation in multiple sclerosis: a longitudinal perfusion MRI study. Brain 127:111-119

165. Jiang Q, Zhang ZG, Ding GL, Zhang L, Ewing JR, Wang L, Zhang R, Li L, Lu M, Meng H, Arbab AS, Hu J, Li QJ, Pourabdollah Nejad DS, Athiraman H, Chopp M (2005) Investigation of neural progenitor cell induced angiogenesis after embolic stroke in rat using MRI. Neuroimage 28:698-707

166. Hiehle JF Jr, Lenkinski RE, Grossman RI, Dousset V, Ramer KN, Schnall MD, Cohen JA, Gonzalez-Scarano F (1994) Correlation of spectroscopy and magnetization transfer imaging in the evaluation of demyelinating lesions and normal appearing white matter in multiple sclerosis. Magn Reson Med 32:285-293

167. De Keyser J, Steen C, Mostert JP, Koch MW (2008) Hypoperfusion of the cerebral white matter in multiple sclerosis: possible mechanisms and pathophysiological significance. J Cereb Blood Flow Metab 28:1645-1651

168. Steen C, Wilczak N, Hoogduin JM, Koch M, De Keyser J (2010) Reduced creatine kinase $B$ activity in multiple sclerosis normal appearing white matter. PLoS One 5:e10811

169. D'haeseleer M, Cambron M, Vanopdenbosch L, De Keyser J (2011) Vascular aspects of multiple sclerosis. Lancet Neurol 10:657-666

170. Brück W, Lucchinetti C, Lassmann H (2002) The pathology of primary progressive multiple sclerosis. Mult Scler 8:93-97

171. Dore-Duffy P, Wencel M, Katyshev V, Cleary K (2011) Chronic mild hypoxia ameliorates chronic inflammatory activity in myelin oligodendrocyte glycoprotein (MOG) peptide induced experimental autoimmune encephalomyelitis (EAE). Adv Exp Med Biol 701:165-173

172. Esen N, Serkin Z, Dore-Duffy P (2013) Induction of vascular remodeling: a novel therapeutic approach in EAE. J Neurol Sci 333:88-92

173. Lu F, Selak M, O'Connor J, Croul S, Lorenzana C, Butunoi C, Kalman B (2000) Oxidative damage to mitochondrial DNA and activity of mitochondrial enzymes in chronic active lesions of multiple sclerosis. J Neurol Sci 177:95-103

174. Haider L, Fischer MT, Frischer JM, Bauer J, Höftberger R, Botond G, Esterbauer H, Binder CJ, Witztum JL, Lassmann H (2011) Oxidative damage in multiple sclerosis lesions. Brain 134:1914-1924. doi:10.1093/brain/awr128

175. Gironi M, Borgiani B, Mariani E, Cursano C, Mendozzi L, Cavarretta R, Saresella M, Clerici M, Comi G, Rovaris M, Furlan R (2014) Oxidative stress is differentially present in multiple sclerosis courses, early evident, and unrelated to treatment. J Immunol Res 2014:961863. doi:10.1155/2014/961863

176. Bolanos JP, Almeida A, Stewart V, Peuchen S, Land JM, Clark JB, Heales SJ (1997) Nitric oxide-mediated mitochondrial damage in the brain: mechanisms and implications for neurodegenerative diseases. J Neurochem 68:2227-2240

177. Aboul-Enein F, Rauschka H, Kornek B, Stadelmann C, Stefferl A, Brück W, Lucchinetti C, Schmidbauer M, Jellinger K, Lassmann H (2003) Preferential loss of myelin-associated glycoprotein reflects hypoxia-like white matter damage in stroke and inflammatory brain diseases. J Neuropathol Exp Neurol 62:25-33

178. Redford EJ, Kapoor R, Smith KJ (1997) Nitric oxide donors reversibly block axonal conduction: demyelinated axons are especially susceptible. Brain 120:2149-2157
179. Amorini AM, Nociti V, Petzold A, Gasperini C, Quartuccio E, Lazzarino G, Di Pietro V, Belli A, Signoretti S, Vagnozzi R, Lazzarino G, Tavazzi B (2014) Serum lactate as a novel potential biomarker in multiple sclerosis. Biochim Biophys Acta 1842:1137-1143. doi:10.1016/j.bbadis.2014.04.005

180. Simone IL, Federico F, Trojano M, Tortorella C, Liguori M, Giannini P, Picciola E, Natile G, Livrea P (1996) High resolution proton MR spectroscopy of cerebrospinal fluid in MS patients. Comparison with biochemical changes in demyelinating plaques. J Neurol Sci 144:182-190

181. Fischer MT, Sharma R, Lim JL, Haider L, Frischer JM, Drexhage J, Mahad D, Bradl M, van Horssen J, Lassmann H (2012) NADPH oxidase expression in active multiple sclerosis lesions in relation to oxidative tissue damage and mitochondrial injury. Brain 135:886-899. doi:10.1093/brain/aws012

182. Campbell GR, Kraytsberg Y, Krishnan KJ, Ohno N, Ziabreva I, Reeve A, Trapp BD, Newcombe J, Reynolds R, Lassmann H, Khrapko K, Turnbull DM, Mahad DJ (2012) Clonally expanded mitochondrial DNA deletions within the choroid plexus in multiple sclerosis. Acta Neuropathol 124:209-220. doi:10.1007/s00401-012-1001-9

183. Pandit A, Vadnal J, Houston S, Freeman E, McDonough J (2009) Impaired regulation of electron transport chain subunit genes by nuclear respiratory factor 2 in multiple sclerosis. J Neurol Sci 279:14-20. doi:10.1016/j.jns.2009.01.009

184. Pache M, Kaiser HJ, Akhalbedashvili N, Lienert C, Dubler B, Kappos L, Flammer J (2003) Extraocular blood flow and endothelin-1 plasma levels in patients with multiple sclerosis. Eur Neurol 49:164-168

185. Speciale L, Sarasella M, Ruzzante S, Caputo D, Mancuso R, Calvo MG, Guerini FR, Ferrante P (2000) Endothelin and nitric oxide levels in cerebrospinal fluid of patients with multiple sclerosis. J Neurovirol 6:S62-66

186. Matsushita T, Isobe N, Kawajiri M, Mogi M, Tsukuda K, Horiuchi M, Ohyagi Y, Kira J (2010) CSF angiotensin II and angiotensin-converting enzyme levels in anti-aquaporin-4 autoimmunity. J Neurol Sci 295:41-45

187. Constantinescu CS, Goodman DB, Grossman RI, Mannon LJ, Cohen JA (1997) Serum angiotensin-converting enzyme in multiple sclerosis. Arch Neurol 54:1012-1015

188. Platten M, Youssef S, Hur EM, Ho PP, Han MH, Lanz TV, Phillips LK, Goldstein MJ, Bhat R, Raine CS, Sobel RA, Steinman L (2009) Blocking angiotensin-converting enzyme induces potent regulatory $\mathrm{T}$ cells and modulates $\mathrm{TH} 1$ - and TH17-mediated autoimmunity. Proc Natl Acad Sci U S A 106:14948-14953

189. Griffioen AW, Molema G (2000) Angiogenesis: potentials for pharmacologic intervention in the treatment of cancer, cardiovascular diseases, and chronic inflammation. Pharmacol Rev 52:237-268

190. Krum JM, Khaibullina A (2003) Inhibition of endogenous VEGF impende revascularization and astroglial proliferation: roles for VEGF in brain repair. Exp Neurol 181:241-257

191. Bouérat L, Fensholdt J, Liang X, Havez S, Nielsen SF, Hansen JR, Bolvig S, Andersson C (2005) Indolin-2-ones with high in vivo efficacy in a model for multiple sclerosis. J Med Chem 48:5412-5414

192. Mohty M, Brissot E, Savani BN, Gaugler B (2013) Effects of bortezomib on the immune system: a focus on immune regulation. Biol Blood Marrow Transplant 19:1416-1420

193. Dredge K, Marriott JB, Dalgleish AG (2002) Immunological effects of thalidomide and its chemical and functional analogs. Crit Rev Immunol 22:425-437

194. Sastry PS (1999) Inhibition of TNF-alpha synthesis with thalidomide for prevention of acute exacerbations and altering the natural history of multiple sclerosis. Med Hypotheses 53:76-77

195. Sharief MK, Thompson EJ (1992) In vivo relationship of tumor necrosis factor-alpha to blood-brain barrier damage in patients with active multiple sclerosis. J Neuroimmunol 38:27-33

196. Faure M, Lejeune JP, Gaucherand M, Thivolet J (1981) PMN leukocytes chemotaxis: inhibition by thalidomide. Pathol Biol (Paris) 9:601-604

197. McHugh SM, Rifkin IR, Deighton J, Wilson AB, Lachmann PJ, Lockwood CM, Ewan PW (1995) The immunosuppressive drug thalidomide induces $T$ helper cell type 2 (Th2) and concomitantly inhibits Th1 cytokine production in mitogen- and antigen-stimulated human peripheral blood mononuclear cell cultures. Clin Exp Immunol 99:160-167

198. Haslett PA, Corral LG, Albert M, Kaplan G (1998) Thalidomide costimulates primary human $T$ lymphocytes, preferentially inducing proliferation, cytokine production, and cytotoxic responses in the CD8+ subset. J Exp Med 187:1885-1892

199. Ryu JK, Jantaratnotai N, McLarnon JG (2009) Thalidomide inhibition of vascular remodeling and inflammatory reactivity in the quinolinic acid-injected rat striatum. Neuroscience 163:601-608 
200. Contino-Pépin C, Parat A, Périno S, Lenoir C, Vidal M, Galons H, Karlik S, Pucci B (2009) Preliminary biological evaluations of new thalidomide analogues for multiple sclerosis application. Bioorg Med Chem Lett 19:878-881

201. MacLean HJ, Freedman MS (2001) Immunologic therapy for relapsing remitting multiple sclerosis. Curr Neurol Neurosci Rep 1:277-85

202. Folkman J, Langer R, Linhardt RJ, Haudenschild C, Taylor S (1983) Angiogenesis inhibition and tumor regression caused by heparin or a heparin fragment in the presence of cortisone. Science 221:719-725

203. Nauck M, Karakiulakis G, Perruchoud AP, Papakonstantinou E, Roth M (1998) Corticosteroids inhibit the expression of the vascular endothelial growth factor gene in human vascular smooth muscle cells. Eur J Pharmacol 341:309-315

204. Jablonska J, Leschner S, Westphal K, Lienenklaus S, Weiss S (2010) Neutrophils responsive to endogenous IFN-beta regulate tumor angiogenesis and growth in a mouse tumor model. J Clin Invest 120:1151-1164

205. Taylor KL, Leaman DW, Grane R, Mechti N, Borden EC, Lindner DJ (2008) Identification of interferon-beta-stimulated genes that inhibit angiogenesis in vitro. J Interferon Cytokine Res 28:733-740

206. Ewalt KL, Schimmel P (2002) Activation of angiogenic signaling pathways by two human tRNA synthetases. Biochemistry 41:13344-13349

207. Thamilarasan M, Hecker M, Goertsches RH, Paap BK, Schröder I, Koczan D, Thiesen HJ, Zettl UK (2013) Glatiramer acetate treatment effects on gene expression in monocytes of multiple sclerosis patients. J Neuroinflammation 10:126. doi:10.1186/1742-2094-10-126

208. Jin H, Su J, Garmy-Susini B, Kleeman J, Varner J (2006) Integrin alpha4beta1 promotes monocyte trafficking and angiogenesis in tumors. Cancer Res $66: 2146-2152$

209. Podar K, Zimmerhackl A, Fulciniti M, Tonon G, Hainz U, Tai YT, Vallet S, Halama N, Jäger D, Olson DL, Sattler M, Chauhan D, Anderson KC (2011) The selective adhesion molecule inhibitor Natalizumab decreases multiple myeloma cell growth in the bone marrow microenvironment: therapeutic implications. Br J Haematol 155:438-448

210. Foster CA, Mechtcheriakova D, Storch MK, Balatoni B, Howard LM, Bornancin F, Wlachos A, Sobanov J, Kinnunen A, Baumruker T (2009) FTY720 rescue therapy in the dark agouti rat model of experimental autoimmune encephalomyelitis: expression of central nervous system genes and reversal of blood-brain-barrier damage. Brain Pathol 19:254-266

211. Miron VE, Schubart A, Antel JP (2008) Central nervous system-directed effects of FTY720 (fingolimod). J Neurol Sci 274:13-17

212. Mousseau Y, Mollard S, Richard L, Nizou A, Faucher-Durand K, Cook-Moreau J, Qiu H, Baaj Y, Funalot B, Fourcade L, Sturtz FG (2012) Fingolimod inhibits PDGF-B-induced migration of vascular smooth muscle cell by down-regulating the S1PR1/S1PR3 pathway. Biochimie 94:2523-2531

213. Pulaski HL, Spahlinger G, Silva IA, McLean K, Kueck AS, Reynolds RK, Coukos G, Conejo-Garcia JR, Buckanovich RJ (2009) Identifying alemtuzumab as an anti-myeloid cell antiangiogenic therapy for the treatment of ovarian cancer. J Transl Med 7:49

214. Arnold P, Mojumder D, Detoledo J, Lucius R, Wilms H (2014) Pathophysiological processes in multiple sclerosis: focus on nuclear factor erythroid-2-related factor 2 and emerging pathways. Clin Pharmacol 6:35-42

215. García-Caballero M, Marí-Beffa M, Medina MÁ, Quesada AR (2011) Dimethylfumarate inhibits angiogenesis in vitro and in vivo: a possible role for its antipsoriatic effect? J Invest Dermatol 131:1347-1355

216. Billington DC (1991) Angiogenesis and its inhibition: potential new therapies in oncology and non-neoplastic diseases. Drug Des Discov 8:3-35

217. Patten SG, Adamcic U, Lacombe K, Minhas K, Skowronski K, Coomber BL (2010) VEGFR2 heterogeneity and response to anti-angiogenic low dose metronomic cyclophosphamide treatment. BMC Cancer 10:683

218. Gora-Tybor J, Blonski JZ, Robak T (2002) Cladribine decreases the level of angiogenic factors in patients with chronic lymphocytic leukemia. Neoplasma 49:145-148

219. Wu X, Zhong H, Song J, Damoiseaux R, Yang Z, Lin S (2006) Mycophenolic acid is a potent inhibitor of angiogenesis. Arterioscler Thromb Vasc Biol 26:2414-2416

220. Brundula V, Rewcastle NB, Metz LM, Bernard CC, Yong WW (2002) Targeting leukocyte MMPs and transmigration Minocycline as a potential therapy for multiple sclerosis. Brain 125:1297-1308

221. Weingart JD, Sipos EP, Brem H (1995) The role of minocycline in the treatment of intracranial $9 \mathrm{~L}$ glioma. J Neurosurg 82:635-640

222. Tamargo RJ, Bok RA, Brem H (1991) Angiogenesis inhibition by minocycline. Cancer Res 51:672-675
223. Yao JS, Chen Y, Zhai W, Xu K, Young WL, Yang GY (2004) Minocycline exerts multiple inhibitory effects on vascular endothelial growth factor-induced smooth muscle cell migration: the role of ERK1/2, PI3K, and matrix metalloproteinases. Circ Res 95:364-371

224. Garrido-Mesa N, Zarzuelo A, Gálvez J (2013) Minocycline: far beyond an antibiotic. Br J Pharmacol 169:337-352. doi:10.1111/bph.12139

225. Hauser SL, Oksenberg JR (2006) The neurobiology of multiple sclerosis: genes, inflammation, and neurodegeneration. Neuron 52:61-76

226. Rovaris M, Confavreux C, Furlan R, Kappos L, Comi G, Filippi M (2006) Secondary progressive multiple sclerosis: current knowledge and future challenges. Lancet Neurol 5:343-354

227. Herrán E, Pérez-González R, Igartua M, Pedraz JL, Carro E, Hernández RM (2013) VEGF-releasing biodegradable nanospheres administered by craniotomy: a novel therapeutic approach in the APP/Ps1 mouse model of Alzheimer's disease. J Control Release 170:111-119

228. Hwang DH, Lee HJ, Park IH, Seok JI, Kim BG, Joo IS, Kim SU (2009) Intrathecal transplantation of human neural stem cells overexpressing VEGF provide behavioral improvement, disease onset delay and survival extension in transgenic ALS mice. Gene Ther 16:1234-1244. doi:10.1038/gt.2009.80

229. Tian $Y Y$, Tang CJ, Wang JN, Feng Y, Chen XW, Wang L, Qiao X, Sun SG (2007) Favorable effects of VEGF gene transfer on a rat model of Parkinson's disease using adeno-associated viral vectors. Neurosci Lett 421:239-244

230. Azzouz M, Ralph GS, Storkebaum E, Walmsley LE, Mitrophanous KA, Kingsman SM, Carmeliet P, Mazarakis ND (2004) VEGF delivery with retrogradely transported lentivector prolongs survival in a mouse ALS model. Nature 429:413-417

231. Sun Y, Jin K, Xie L, Childs J, Mao XO, Logvinova A, Greenberg DA (2003) VEGF-induced neuroprotection, neurogenesis, and angiogenesis after focal cerebral ischemia. J Clin Invest 111:1843-1851

232. Tang Z, Yin JX, Han P, Gan Y, Coons SW, Wang C, Maalouf M, Shi J (2013) Pertussis toxin attenuates experimental autoimmune encephalomyelitis by upregulating neuronal vascular endothelial growth factor. Neuroreport 24:469-475. doi:10.1097/WNR.0b013e3283619fc8

233. Nowak DG, Woolard J, Amin EM, Konopatskaya O, Saleem MA, Churchill AJ, Ladomery MR, Harper SJ, Bates DO (2008) Expression of pro- and anti-angiogenic isoforms of VEGF is differentially regulated by splicing and growth factors. J Cell Sci 121:3487-3495. doi:10.1242/jcs.016410

234. Magnussen AL, Rennel ES, Hua J, Bevan HS, Beazley Long N, Lehrling C, Gammons M, Floege J, Harper SJ, Agostini HT, Bates DO, Churchill AJ (2010) VEGF-A165b is cytoprotective and antiangiogenic in the retina. Invest Ophthalmol Vis Sci 51:4273-4281. doi:10.1167/iovs.09-4296

235. MacMillan CJ, Doucette CD, Warford J, Furlong SJ, Hoskin DW, Easton AS (2014) Murine experimental autoimmune encephalomyelitis is diminished by treatment with the angiogenesis inhibitors B20-4.1.1 and angiostatin (K1-3). PLoS One 9:e89770

236. Lopez-Ramirez MA, Wu D, Pryce G, Simpson JE, Reijerkerk A, King-Robson J, Kay O, de Vries HE, Hirst MC, Sharrack B, Baker D, Male DK, Michael GJ, Romero IA (2014) MicroRNA-155 negatively affects blood-brain barrier function during neuroinflammation. FASEB J. doi:10.1096/fj.13-248880 fj.13-248880

237. Munger KL, Zhang SM, O'Reilly E, Hernán MA, Olek MJ, Willett WC, Ascherio A (2004) Vitamin D intake and incidence of multiple sclerosis. Neurology 62:60-65

238. Grundmann M, Haidar M, Placzko S, Niendorf R, Darashchonak N, Hubel CA, von Versen-Höynck F (2012) Vitamin D improves the angiogenic properties of endothelial progenitor cells. Am J Physiol Cell Physiol 303:C954-962

239. Gazzerro P, Proto MC, Gangemi G, Malfitano AM, Ciaglia E, Pisanti S, Santoro A, Laezza C, Bifulco M (2012) Pharmacological actions of statins: a critical appraisal in the management of cancer. Pharmacol Rev 64:102-146

240. Wang B, Sun L, Tian Y, Li Z, Wei H, Wang D, Yang Z, Chen J, Zhang J, Jiang $R$ (2012) Effects of atorvastatin in the regulation of circulating EPCS and angiogenesis in traumatic brain injury in rats. J Neurol Sci 319:117-123

241. Birnbaum G, Cree B, Altafullah I, Zinser M, Reder AT (2008) Combining beta interferon and atorvastatin may increase disease activity in multiple sclerosis. Neurology 71:1390-1395

242. Kamm CP, El-Koussy M, Humpert S, Findling O, Burren Y, Schwegler G, Donati F, Müller M, Müller F, Slotboom J, Kappos L, Naegelin Y, Mattle HP, SWABIMS Study Group (2014) Atorvastatin added to interferon beta for relapsing multiple sclerosis: 12-month treatment extension of the randomized multicenter SWABIMS Trial. PLoS One 9:e86663

243. Stüve O, Youssef S, Weber MS, Nessler S, von Büdingen HC, Hemmer B, Prod'homme T, Sobel RA, Steinman L, Zamvil SS (2006) Immunomodulatory 
synergy by combination of atorvastatin and glatiramer acetate in treatment of CNS autoimmunity. J Clin Invest 116:1037-1044

244. Sorensen PS, Lycke J, Erälinna JP, Edland A, Wu X, Frederiksen JL, Oturai A, Malmeström C, Stenager E, Sellebjerg F, Sondergaard HB, SIMCOMBIN study investigators (2011) Simvastatin as add-on therapy to interferon $\beta$-1a for relapsing-remitting multiple sclerosis (SIMCOMBIN study): a placebocontrolled randomised phase 4 trial. Lancet Neurol 10:691-701

245. Dell'Acqua ML, Lorenzini L, D'Intino G, Sivilia S, Pasqualetti P, Panetta V, Paradisi M, Filippi MM, Baiguera C, Pizzi M, Giardino L, Rossini PM, Calzà L (2012) Functional and molecular evidence of myelin- and neuroprotection by thyroid hormone administration in experimental allergic encephalomyelitis. Neuropathol Appl Neurobiol 38:454-470. doi:10.1111/.1365-2990.2011.01228.x

246. Bartels C, Späte K, Krampe H, Ehrenreich H (2008) Recombinant human Erythropoietin: novel strategies for neuroprotective/neuro-regenerative treatment of multiple sclerosis. Ther Adv Neurol Disord 1:193-206. doi:10.1177/1756285608098422

247. Créange A, Lefaucheur JP, Balleyguier MO, Galactéros F (2013) Iron depletion induced by bloodletting and followed by rhEPO administration as a therapeutic strategy in progressive multiple sclerosis: a pilot, open-label study with neurophysiological measurements. Neurophysiol Clin 43:303-312. doi:10.1016/j.neucli.2013.09.004

248. Ehrenreich H, Fischer B, Norra C, Schellenberger F, Stender N, Stiefel M, Sirén AL, Paulus W, Nave KA, Gold R, Bartels C (2007) Exploring recombinant human erythropoietin in chronic progressive multiple sclerosis. Brain 130:2577-2588

249. Najmi Varzaneh F, Najmi Varzaneh F, Azimi AR, Rezaei N, Sahraian MA (2014) Efficacy of combination therapy with erythropoietin and methylprednisolone in clinical recovery of severe relapse in multiple sclerosis. Acta Neurol Belg :114, 114: doi: 10.1007/s13760-014-0286-y

250. Balashov KE, Aung LL, Dhib-Jalbut S, Keller IA (2011) Acute multiple sclerosis lesion: conversion of restricted diffusion due to vasogenic edema. J Neuroimaging 21:202-204. doi:10.1111/j.1552-6569.2009.00443.x

251. Tievsky AL, Ptak T, Farkas J (1999) Investigation of apparent diffusion coefficient and diffusion tensor anisotrophy in acute and chronic multiple sclerosis lesions. AJNR Am J Neuroradiol 20:1491-1499

252. Zlokovic BV (2008) The blood-brain barrier in health and chronic neurodegenerative disorders. Neuron 57:178-201

253. Muramatsu R, Takahashi C, Miyake S, Fujimura H, Mochizuki H, Yamashita T (2012) Angiogenesis induced by CNS inflammation promotes neuronal remodeling through vessel-derived prostacyclin. Nat Med 18:1658-1664

254. Li L, Welser JV, Dore-Duffy P, del Zoppo GJ, Lamanna JC, Milner R (2010) In the hypoxic central nervous system, endothelial cell proliferation is followed by astrocyte activation, proliferation, and increased expression of the alpha 6 beta 4 integrin and dystroglycan. Glia 58:1157-1167

255. Palavra F, Marado D, Mascarenhas-Melo F, Sereno J, Teixeira-Lemos E, Nunes CC, Gonçalves G, Teixeira F, Reis F (2013) New markers of early cardiovascular risk in multiple sclerosis patients: oxidized-LDL correlates with clinical staging. Dis Markers 34:341-348. doi:10.3233/DMA-130979

256. Chaitanya GV, Omura S, Sato F, Martinez NE, Minagar A, Ramanathan M, Guttman BW, Zivadinov R, Tsunoda I, Alexander JS (2013) Inflammation induces neuro-lymphatic protein expression in multiple sclerosis brain neurovasculature. J Neuroinflammation 10:125. doi:10.1186/1742-2094-10-125

257. Sarchielli P, Di Filippo M, Ercolani MV, Chiasserini D, Mattioni A, Bonucci M, Tenaglia S, Eusebi P, Calabresi P (2008) Fibroblast growth factor-2 levels are elevated in the cerebrospinal fluid of multiple sclerosis patients. Neurosci Lett 435:223-228

258. Rieckmann P, Albrecht M, Ehrenreich H, Weber T, Michel U (1995) Semi-quantitative analysis of cytokine gene expression in blood and cerebrospinal fluid cells by reverse transcriptase polymerase chain reaction. Res Exp Med (Berl) 195:17-29

259. Giovannoni G (1998) Cerebrospinal fluid and serum nitric oxide metabolites in patients with multiple sclerosis. Mult Scler 4:27-30

260. Sarchielli P, Orlacchio A, Vicinanza F, Pelliccioli GP, Tognoloni M, Saccardi C, Gallai $\checkmark$ (1997) Cytokine secretion and nitric oxide production by mononuclear cells of patients with multiple sclerosis. J Neuroimmunol 80:76-86

261. Maimone D, Gregory S, Arnason BG, Reder AT (1991) Cytokine levels in the cerebrospinal fluid and serum of patients with multiple sclerosis. J Neuroimmunol 32:67-74

262. Hauser SL, Doolittle TH, Lincoln R, Brown RH, Dinarello CA (1990) Cytokine accumulations in CSF of multiple sclerosis patients: frequent detection of interleukin-1 and tumor necrosis factor but not interleukin-6. Neurology 40:1735-1739
263. Sharief MK, Hentges R (1991) Association between tumor necrosis factor-alpha and disease progression in patients with multiple sclerosis. N Engl J Med 325:467-472

264. Kahl KG, Kruse N, Toyka KV, Rieckmann P (2002) Serial analysis of cytokine mRNA profiles in whole blood samples from patients with early multiple sclerosis. J Neurol Sci 200:53-55

265. Link J (1994) Interferon-gamma, interleukin-4 and transforming growth factor-beta mRNA expression in multiple sclerosis and myasthenia gravis. Acta Neurol Scand Suppl 158:1-58

266. Rieckmann P, Albrecht M, Kitze B, Weber T, Tumani H, Broocks A, Lüer W, Helwig A, Poser S (1995) Tumor necrosis factor-alpha messenger RNA expression in patients with relapsing-remitting multiple sclerosis is associated with disease activity. Ann Neurol 37:82-88

267. Nicoletti F, Di Marco R, Patti F, Reggio E, Nicoletti A, Zaccone P, Stivala F, Meroni PL, Reggio A (1998) Blood levels of transforming growth factor-beta 1 (TGF-beta1) are elevated in both relapsing remitting and chronic progressive multiple sclerosis (MS) patients and are further augmented by treatment with interferon-beta 1b (IFN-beta1b). Clin Exp Immunol 113:96-99

268. Rollnik JD, Sindern E, Schweppe C, Malin JP (1997) Biologically active TGF-beta 1 is increased in cerebrospinal fluid while it is reduced in serum in multiple sclerosis patients. Acta Neurol Scand 96:101-105

269. Hollifield RD, Harbige LS, Pham-Dinh D, Sharief MK (2003) Evidence for cytokine dysregulation in multiple sclerosis: peripheral blood mononuclear cell production of pro-inflammatory and anti-inflammatory cytokines during relapse and remission. Autoimmunity 36:133-141

270. Hohnoki K, Inoue A, Koh CS (1998) Elevated serum levels of IFN-gamma, IL-4 and TNF-alpha/unelevated serum levels of IL-10 in patients with demyelinating diseases during the acute stage. J Neuroimmunol 87:27-32

271. Avolio C, Ruggieri M, Giuliani F, Liuzzi GM, Leante R, Riccio P, Livrea P, Trojano M (2003) Serum MMP-2 and MMP-9 are elevated in different multiple sclerosis subtypes. J Neuroimmunol 136:46-53

272. Fainardi E, Castellazzi M, Tamborino C, Trentini A, Manfrinato MC, Baldi E, Tola MR, Dallocchio F, Granieri E, Bellini T (2009) Potential relevance of cerebrospinal fluid and serum levels and intrathecal synthesis of active matrix metalloproteinase-2 (MMP-2) as markers of disease remission in patients with multiple sclerosis. Mult Scler 15:547-554

273. Bar-Or A, Nuttall RK, Duddy M, Alter A, Kim HJ, Ifergan I, Pennington CJ, Bourgoin P, Edwards DR, Yong WW (2003) Analyses of all matrix metalloproteinase members in leukocytes emphasize monocytes as major inflammatory mediators in multiple sclerosis. Brain 126:2738-2749

274. Lee MA, Palace J, Stabler G, Ford J, Gearing A, Miller K (1999) Serum gelatinase B, TIMP-1 and TIMP-2 levels in multiple sclerosis. A longitudinal clinical and MRI study. Brain 122:191-197

275. Fainardi E, Castellazzi M, Bellini T, Manfrinato MC, Baldi E, Casetta I, Paolino E, Granieri E, Dallocchio F (2006) Cerebrospinal fluid and serum levels and intrathecal production of active matrix metalloproteinase-9 (MMP-9) as markers of disease activity in patients with multiple sclerosis. Mult Scler 12:294-301

276. Leppert D, Ford J, Stabler G, Grygar C, Lienert C, Huber S, Miller KM, Hauser SL, Kappos L (1998) Matrix metalloproteinase-9 (gelatinase B) is selectively elevated in CSF during relapses and stable phases of multiple sclerosis. Brain 121:2327-2734

277. Boz C, Ozmenoglu M, Velioglu S, Kilinc K, Orem A, Alioglu Z, Altunayoglu V (2006) Matrix metalloproteinase-9 (MMP-9) and tissue inhibitor of matrix metalloproteinase (TIMP-1) in patients with relapsing-remitting multiple sclerosis treated with interferon beta. Clin Neurol Neurosurg 108:124-1248

278. Bomprezzi R, Ringnér M, Kim S, Bittner ML, Khan J, Chen Y, Elkahloun A, Yu A, Bielekova B, Meltzer PS, Martin R, McFarland HF, Trent JM (2003) Gene expression profile in multiple sclerosis patients and healthy controls: identifying pathways relevant to disease. Hum Mol Genet 12:2191-2199

279. Duan H, Luo Y, Hao H, Feng L, Zhang Y, Lu D, Xing S, Feng J, Yang D, Song L, Yan X (2013) Soluble CD146 in cerebrospinal fluid of active multiple sclerosis. Neuroscience 235:16-26. doi:10.1016/j.neuroscience.2013.01.020

doi:10.1186/s40478-014-0084-z

Cite this article as: Girolamo et al: Angiogenesis in multiple sclerosis and experimental autoimmune encephalomyelitis. Acta Neuropathologica Communications 2014 2:84. 